\title{
14. Dinleme becerisinin dilsel yönü
}

\section{Selim EMİROĞLU1}

APA: Emiroğlu, S. (2021). Dinleme becerisinin dilsel yönü. RumeliDE Dil ve Edebiyat Araşttrmalar Dergisi, (24), 259-282. DOI: 10.29000/rumelide.995299.

$\ddot{\mathbf{O} z}$

Bu çalışmada; dinlemenin neden bir dil becerisi olduğu, dilsel yönünün ne ifade ettiği, iletişim ve dinleme ilişkisi, konuşmacı, dinleyici ve dilsel verinin dinleme üzerindeki etkileri, dilsel verinin çözümlenmesinde dinleyicinin özellik, görev ve sorumlulukları ile dinlemenin dilsel yönüyle eğitimi ele alınmıştır. Bilindiği üzere insan ilişkileri ve iletişim, dil sayesinde gerçekleşir. İletişimde kullanılan dilsel veri, dinlemeyi etkiler. Dinleme dilsel bir beceridir. Dinleme, işitme üzerine temellenir ancak işitmeden farklıdır. Dinlemeyi olumlu veya olumsuz etkileyen birçok faktör vardır. Bir konuşmanın içeriği kadar konuşmacının dil kullanımı ve özellikleri de dinlemeyi etkiler. Dinleyicinin, konuşmayı dilsel yönden anlamlı kılacak özelliklere sahip olması gerekir. Kitap, makale, tez ve araştırmalarda dinlemenin, daha çok, iletişimsel yönüne dikkat çekilir. Çalışmanın amacı, bir iletişim becerisi olarak da bilinen dinlemenin dilsel yönünü ortaya koymaktır. Bu amaçla; ilgili literatür taranmış, dokümanlara ve yayınlara ulaşılmış, dinlemenin Türkçede dilsel bakımdan yeri ve önemiyle ilgili tespitler sıralanmıştır. Konuşmayı oluşturan dilsel ifadeden, dinleyicinin dil yetisine kadar dinleme sürecine etki eden birçok özellik, çeşitli bulgu ve değerlendirmelerle yansıtılmıştır. Nitel desendeki bu çalışmada, kaynak tarama tekniğinden faydalanılmıştır. Çalışma sonucunda; dinlemenin diğer becerilerle birlikte değerlendirilmesi, dinleme eğitimiyle ilgili yayınların, dinlemenin iletişimle ilişkisine değinmek kadar dilsel yönüne de vurgu yapması, dinlemeye etki eden faktörlere ilişkin farkındalık geliştirilmesi ve dinlemenin dilsel yönden eğitimine dair çalışmalar yapılması gerektiği belirtilmiştir.

Anahtar kelimeler: dilsel veriler, dinleme, dinleyici, eğitim, konuşmacı

\section{The linguistic aspect of listening skill}

\begin{abstract}
In this study, the reason why listening is a language skill, what its linguistic aspect means, the relationship of communication and listening, the effects of speaker, listener and linguistic data on listening, listener's characteristics, duties, and responsibilities in analyzing linguistic data and the listening education with its linguistic aspect have been discussed. As it is known, human relations and communication take place thanks to language. Linguistic data used in communication affects listening. Listening is a linguistic skill. Listening is based on hearing but is different from hearing. There are many factors that affect listening positively or negatively. The speaker's language use and characteristics affect listening as well as the content of a speech. The listener must have the characteristics that will make the speech linguistically meaningful. In books, articles, theses and researches, attention is often drawn to the communicative aspect of listening. The aim of the study is to reveal the linguistic aspect of listening, also known as a communication skill. For this purpose, the
\end{abstract}

Doç. Dr., İstanbul Aydın Üniversitesi, Eğitim Fakültesi, Türkçe ve Sosyal Bilimler Eğitimi Bölümü, Türkçe Eğitimi ABD (İstanbul, Türkiye), selimemiroglu@aydin.edu.tr, ORCID ID: 00oo-0003-4892-9575 [Araştırma makalesi, Makale kayıt tarihi: 28.05.2021-kabul tarihi: 20.09.2021; DOI: 10.29000/rumelide.995299

Adres $\mid$ Address

RumeliDE Dil ve Edebiyat Araştırmaları Dergisi $\quad$ RumeliDE Journal of Language and Literature Studies

Osmanağa Mahallesi, Mürver Çiçeği Sokak, No:14/8 Osmanağa Mahallesi, Mürver Çiçeği Sokak, No:14/8

Kadıköy - ISTANBUL / TÜRKIYE 34714 Kadıköy - ISTANBUL / TURKEY 34714

e-posta: editor@rumelide.com e-mail: editor@rumelide.com,

tel: +90 505 7958124, +90 2167730616 phone: +90 505 7958124, +90 2167730616 
relevant literature has been scanned, documents and publications have been reached, and the determinations about the linguistic place and importance of listening in Turkish have been listed. Many features that affect the listening process, from the linguistic expression that make up the speech to the linguistic competence of the listener, have been reflected with various findings and evaluations. In this qualitative study, the literature review technique has been used. As a result of the study, it has been stated that listening should be evaluated together with other skills, publications on listening education should emphasize the linguistic aspect of listening as well as referring to its relationship with communication, awareness of the factors affecting listening should be developed, and studies should be carried out on the listening education with its linguistic aspect.

Keywords: linguistic data, listener, listening, education, speaker

\section{Giriş}

\section{Dil nedir?}

Doğal bir anlaşma aracı olan dilin, herkesin hemfikir olduğu ortak tanımları olsa da, dilin özünü tüm detaylarıyla yansıtan bir tanımını oluşturmak güçtür. "Dilin insanın fiziksel, kültürel, sosyal, ruhsal vb. tüm değerleriyle birleşmiş, kaynaşmış nitelik taşıması bütüncül bir tanımın ortaya konulamamasına yol açmıştır” (Eker, 2004: 3). Dilin dille anlatılması, dilin dile getirilmesi de paradoksal bir durum oluşturur.

Belli sayıdaki sesin sonsuz sayıda sözcük ve anlam oluşturabilmesi, insana ait olmasına rağmen insanüstü özellikler göstermesi, dilin mucizevi özellikleridir. Duygu ve düşüncelerin gölgesi olan dil; bir aynadır, tepkidir. Toplum dile ne vermişse dil de onu kültürel kodlarla topluma geri verir. İnsanın anlattıkları dile gelmez, dilden gelir. İnsanlar dili değil, bir anlamda, dil insanları kullanır ve varlığını insan üzerinden geleceğe taşır.

\section{Dinleme nedir, ne değildir?}

Dinleme, işitme değildir. Dinleme, işitme üzerine temellenir ancak işitmeden farklıdır. "İşitme, bize dünyamızı dinleme şansını veren, sesleri algılayıp onları ayırt etmemizi sağlayan duyumuzdur. Dinlemek ise bu işaretleri anlamlandırma ve onları birer ifadeye dönüştürme işlemidir" (Shafir, 2003: 56). Her işiten dinlemez ancak her dinlemenin öncesinde işitme vardır. Psikolojik ve fizyolojik anlamda sağlıklı bir bünye, süreci bu şekilde tamamlar.

Dinleme, dilsel verinin çözümlendiği önemli bir öğrenme alanıdır. Dinleme, sesle başlasa da sesten öte, duygu ve düşünceyi anlamak ve anlaşllan şeye uygun tepki vermektir. "Sözlü iletişim sürecinde etkili anlama ve cevap verme yeteneğidir” (Johnson, 1951: 58; akt. Aytan, 2011: 24). Dinleme, bir farkındalık gerektirir. "Dinlemek; dinleyen kişinin, konuşan kişinin sesine, sözcük seçimine, tonlamasına, hızına ve beden diline karşı duyarlı olması demektir” (Mackay, 1997: 4). Bu duyarlıkla birlikte, dinlemenin, bir anlama gayreti olduğu bilinmelidir. "Dinleme karşı tarafı edilgen bir yapıda izleme değil, iletişimin tam olarak gerçekleşmesi için iletiyi tam olarak alma ve yorumlama çabasıdı"” (Umagan, 2007: 149). Benzer bir açıklamayla dinleme "Konuşan kişinin vermek istediği mesajı, pürüzsüz olarak anlayabilme ve söz konusu uyarana karşı tepkide bulunabilme etkinliğı” (Demirel ve Şahinel, 2006: 72) olarak belirtilir.

Dil, bilme ve yapabilmeyi gerektirir. Dilin yapabilme boyutu dinleme, konuşma, okuma ve yazma; bilme boyutu dil bilgisi, sözcük bilgisi, metin bilgisi ve edebî bilgiden oluşur. Beceri ile bilgi ilişkilendirilebilir

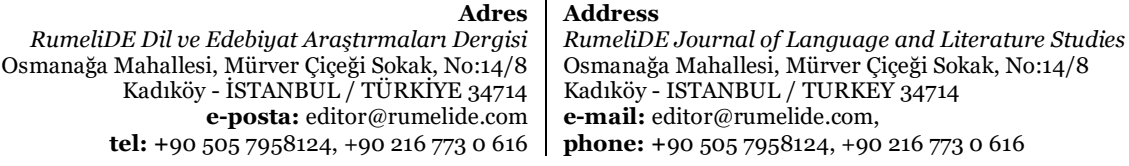


ve beceri bilgiden önemlidir. Beceri, bilgiyi işleme koymaktır. Bu yönüyle dinleme, dile ait bilginin ses üzerinden kullanımıdır.

\section{Olumlu ve olumsuz dinleme}

Dinlemeyi olumlu veya olumsuz etkileyen birçok faktör [zekâ, cinsiyet, yaş, kelime serveti, psikolojik durum, duygular (sabır, sempati, nefret, kıskançlık vb.), çeşitli davranışlar (dinlerken sözcük cımbızlamak, sözlere sansür uygulamak, sözü bağlamından koparmak vb.), alışkanlıklar, göndericinin özellikleri, ön yargılar, stres, dikkat, iç konuşmalar, odaklanma, fizyolojik durum, niyet, yorgunluk, uykusuzluk, ilgi, konu, ortam vb.] vardır. Bunlar dilsel verinin alınması, işlenmesi, yorumlanması ve değerlendirilmesinde hatta bir dönüte dönüşmesinde etkilidir. Bu nedenle dilsel veriyi herkesin aynı şekilde anlaması ve değerlendirmesini beklemek doğru olmaz. Bir alan araştırmasında (Dinçel, 2018: 205-244) söz konusu faktörleri içeren yayınlar sıralanmıştır.

Dinleme, insanın günlük hayatındaki ve eğitim-öğretim ortamlarındaki başarısına etki eder. Birçok araştırmada (Peterson ve Karschnik, 2011; Tompkins, 1998; Çankaya, 2004) dinlemenin, insanın günlük faaliyetlerinin olduğu gibi, akademik faaliyetlerinin de \%5o'den fazlasını karşıladığı belirtilir. "Çalışmaların gösterdiğine göre ilköğretim öğrencilerinin sınıfta geçirdikleri sürenin ortalama \%57,5’ini dinlemeye ayırmaları beklenmektedir. Bu süre, lise öğrencileri için \%66 ve üniversite öğrencileri içinse \%52 ila \%9o arasında değişmektedir" (Shafir, 2003: 288). İnsanların büyük bir kısmı dinleme becerisini gerçek anlamda ve kendi içinde \%100 oranında kullanamaz. Yanlış anlamalar, tekrarlar, hedefi ıskalayan açıklamalar, gereksiz polemikler, tartışmalar vb.; dinlemenin belki \%5-\%10 oranında kullanılmasindan kaynaklanır.

\section{Dinleme türleri}

Birçok dinleme türü sayllabilir. Katılımlı, katılımsız, eleştirel, iletişimsel, terapatik, estetik, empatik, tuzak kurucu, seçici, iyileştirici, bilgi almaya dönük vs. Bunların özünde dilsel verilerin anlaşılması, yorumlanması, değerlendirmesi ve tepkide bulunulması yer alır. Söz konusu bilgiyi dilsel bir çözümlemeye tabi tutmak, dinlemenin başında da olabilir, sonunda da. Bazen dilsel veri, dinleme ortamından uzakta, belirli bir zaman sonra anlaşılır. Tepki de içte kalır, açı̆̆a çıkmaz.

Seçerek veya seçici dinlemede çeşitli tercihler vardır. "Dinleme bir yönüyle kişinin tercihine bağlı olarak seçerek ve isteyerek algıladı̆̆ı sesler bütünü olduğundan seçicilik söz konusudur” (Aktaş ve Gündüz, 2004: 247). Dinleme amaciyla konuşma içeriği seçici bir dinlemeye neden olur. "Dinleyiciler her söze ve ifadeye dikkat edemezler. Onlar dinleme amacına göre dinlerler ve seçici biçimde hareket ederler. Bir metnin iletişim amacı ve içeriği hakkındaki bilgi durumu dinleyiciye dinleyip dinlememek konusunda karar vermesine ve hangi süreçlere dikkatini yoğunlaştıracağına yardım eder" (Güneş, 2016: 89). Ancak bu tür bir dinlemenin, kullanıma göre, olumlu ve olumsuz özellikleri bulunur. Dinleyici, maruz kaldığı veya dinlediği konuşmalardan işine/işe yarayanları çekip alabilir ve bir anlamda konuşmayı gerekli ve gereksiz özellikler yönüyle ayıklar. Bu tür bir dinleme olumludur. Fakat dinleyici, konuşmada sadece ilgi ve ihtiyaçlarına hitap eden noktaları dikkate alıyorsa seçici algısı nedeniyle olumsuz bir dinleme içindedir. Çünkü ilgi ve ihtiyaçları dışında olup da onun için önem taşıyan noktaları gözden kaçırır. Konuşanın açı̆̆ını yakalamaya dönük seçici bir dinlemenin, iyimser özellikte olmamasına rağmen, nitelikli bir dinleme olduğu söylenebilir. Çünkü kişi, kötü bir niyet içinde olsa bile, dinleme derinlikli ve başarılıdır. Dinlemeye değil de, "dinlememeye” odaklı dinlemelerde (pasif, gönülsüz, ilgisiz vb.) ise dilsel verinin etkili, derinlikli, çağrışımlı ve uzun vadeli çözümlenmesi ve değerlendirilmesi söz konusu olmaz.

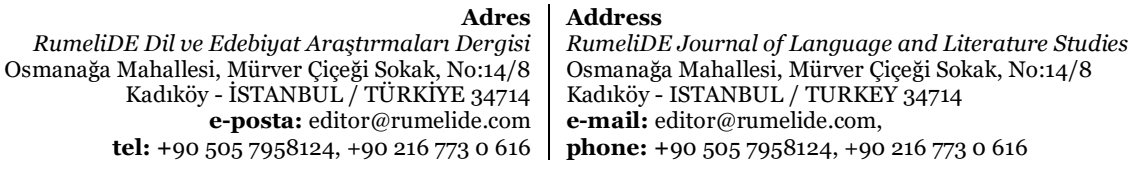




\section{Dinlemenin amacı nedir, ne olabilir?}

Bu sorunun duruma, çeşitli niyet ve amaçlara göre değişen cevapları vardır. Dinlemenin temel gayesi; bilgi edinme, öğrenme, zevk alma, merakı giderme, saygı, mecburiyet, can sıkıntısını giderme, eğlenme, dertleşme, tuzağa düşürme, konuşma malzemesi toplama vb. olabilir. Bu noktada bilinmesi gereken, dinlemenin amacından çok dinleme sürecinin önemli olduğudur. "En iyi dinleyiciler dinlemeyi bir amaçtan çok bir süreç olarak görürler” (Shafir, 2003: 44). Amaca veya sonuca değil de sürece odaklı bir dinleme, etkili iletişimler oluşturur.

Dinleme, dilsel verinin anlaşılması ve çözümlenmesini gerektirir. Ancak söz konusu dilsel veri, amacın gerisinde kahır. Eğitimler de amaca göre yapılır. Örneğin, estetik dinlemede, bir etkinlik (drama, şiir okuma çalışmaları vb.) yapan çocuklar, ara verdiklerinde 10 dakika şarkı dinlerler. Ancak bu dinlemede amaç, şarkının (fon müzik biçiminde olmayan şarkıların) sözlerini anlamak, yorumlamak vs. değildir. Zihnin arka planında şarkının sözleri çözümleniyor olsa bile öncelikli amaç; rahatlamak, zevk almak ve gevşemektir.

\section{Dinlemenin fizyolojik, psikolojik ve zihinsel özellikleri}

Dinleme kulakla yapılmaz, zihinsel bir işlemdir; beyinde gerçekleşir ve dinlemede kavramlar harekete geçer. Bu, dinlemenin bilişsel yönünü yansıtır. İnsanın, neyi duyup neyi duymayacağına karar vermesi ise psikolojiktir. Dinleme kulağı yerine belki dinleme dimağı gerekir. Çünkü kulak sadece bir araçtır. Nasıl ki göz, bir mercek görevi görür ve görme eylemini beyin gerçekleştirirse aynı durum kulak için de geçerlidir. Kulak gerekli "alma” işlemini yapar ancak çözümleme ve değerlendirme beynin işidir. Beyin dilsel verileri bir sünger gibi emerken kullandığı filtrelerle neyin işe yarar olup olmadığına, hatırlanıp hatırlanmaması gerektiğine karar verir.

Her türlü alanda ve bilimsel literatürde, beynin çalışma prensiplerine ilişkin atıflar vardır. Dinleme de doğrudan beyinle ilgilidir. Beyin, vücudun yöneticisidir ve diğer organlardan farklı olarak birçok önemli özelliğe sahiptir. Bir dil işlemcisi olan beyinde "Broca alanı cümle kurulması, Wernicke alanı dili anlama ile ilgilidir" (Özbay, 2009: 6). Beynin işlemleri denilen zihinsel beceriler (zihinde canlandırma, karşılaştırma, tahminde bulunma, sıralama, sınıflandırma, sebep sonuç ilişkisi kurma, inceleme, düzenleme, değerlendirme vb.), dinleme becerisiyle eşgüdüm halinde çalışır.

Duyma engeli olan bireyler olduğu kadar dinleme engeli olan bireyler de vardır. Zihinsel sağırlık, sinirsel sağırlık kadar önemlidir. Sözlerin etkili bir şekilde anlaşılması ve kavranması; kulak kadar zihnin de dört açılmasını gerektirir. Aktarılan mesajın bütünüyle ve eksiksiz anlaşılması için zihnin alıcıları tetikte olmalıdır. Araya giren parazitleri ayıklayarak, ön yargısız bir şekilde, gerçekte ne demek istendiğine odaklanarak, can kulağıyla dinlemek gerekir.

Odaklanma ve dikkat, dilsel veriyi anlamak ve yorumlamak için önceliklidir. İnsan, dikkatini artırarak anlamayı, anlayışını iyileştirir. Dinlemenin duyma olmadığını, görmenin bakma olmadığını ve anlamak için odaklanmak gerektiğini bilmeli; buna göre bir dikkat göstermelidir. Dinleyici, kulağının ardıyla dinlemek yerine kulak kesilmelidir.

Dinlemede belleğin önemli bir yeri vardır. Bir konuşmada, bir önceki cümleyi hatırlayarak bir sonraki cümle ile ilişkilendirmek ve özellikle uzun cümlelerde bağlantıy koparmamak için, bellek etkili bir şekilde kullanılmalıdır. Hem uzun hem de kısa süreli belleğin hatta daha çok kısa süreli belleğin, aktif bir şekilde çalışması gerekir. "Dinleme sırasında kısa süreli belleğe aşırı bir yüklenme olduğu için

\footnotetext{
\begin{tabular}{r|l} 
Adres & Address \\
RumeliDE Dil ve Edebiyat Araştırmaları Dergisi & RumeliDE Journal of Language and Literature Studies
\end{tabular}

Osmanağa Mahallesi, Mürver Çiçeği Sokkak, No:14/8 $\quad$ Osmanağa Mahallesi, Mürver Çiçeği Sokak, No:14/8

Kadıköy - ÍSTANBUL / TÜRKIYE 34714 Kadıköy - ISTANBUL / TURKEY 34714

e-posta: editor@rumelide.com e-mail: editor@rumelide.com,

tel: +90 505 7958124, +90 2167730616 phone: +90 505 7958124, +90 2167730616
} 
söylenenlerin yüzde yüzünün belleğimize aktarımı söz konusu olmamaktadır” (İşeri, 2008: 172). Örneğin, röportajlarda bir anda gelen birden fazla soru, belleği güçlü olan konuşmacılar tarafından hafızada tutulup cevaplandırılabilir ancak belleği güçlü olmayan bir konuşmacı, soruları hatırlamakta güçlük çekecektir. Bu durumda not almak uygundur.

\section{Dinlemede bağlam}

Bağlam, bir sözcüğün cümledeki yerinden fazlası olup iletişimin bir parçası olan dinlemede oldukça önemlidir. "Bağlam, iletişimcilerin içinde bulundukları durum, yer, zaman, dış dünya, kültür, katılımcıların rolleri, birbirleri hakkında bildikleri-bilmedikleri ve birbirleriyle olan ilişkileri vs.nin hepsini kapsayan bir anlam taşımaktadır" (Çakır, 2014: 10). Bağlam, konuşma anını bağlar, kalıcı kılar, hafızaya yükler; bir atmosfer gibi çepeçevre her şeyi kuşatır.

\section{Dinlemede gürültü}

Sözcüklerin, seslerin ve cümlelerin oluşturduğu gürültü; dışarıdan ve içeriden kaynaklanan, iletişimi engelleyen diğer gürültü ve parazitler kadar önemlidir. Argo konuşma, yerel dilde konuşma vs. birer gürültü unsurudur. Gürültü, dinlemenin dilsel yönünü etkileyen önemli bir faktördür. "Gürültü; göndericiden kaynaklanan etkenler, alıcıdan kaynaklanan etkenler ve kanaldan kaynaklanan etkenler olarak üçe ayrılır. Kaynaklarına bağlı olarak da üçe ayrılır: fiziksel gürültü, nörofizyolojik gürültü, psikolojik gürültü” (Kaya, 2014: 10). Doğadaki sesler, insan sesleri, makine ve araçların çıkardığı sesler, maruz kalınan müzik, insanın refeksif tepkileri (aksırma, öksürme...) vb. gürültüdür. Asıl önemli olan içteki gürültüdür. "İnsanlar arasındaki iletişim aksaklıklarında psikolojik gürültünün büyük bir payı vardır" (İmer, Kocaman ve Özsoy, 2011: 146). Bu tür bir gürültü, dinlemede önemli kayılara neden olur.

\section{1. Çalışmanın amacı}

$\mathrm{Bu}$ çalışmanın amacı, bir iletişim becerisi olarak da ele alınan dinlemenin dilsel yönünü ön plana çıkarmaktır. Bu amaç doğrultusunda aşağıdaki sorulara cevap aranacaktır:

"Dinleme neden bir dil becerisidir?"

“Dinlemenin dilsel yönü nedir?”

"Dinlemenin dilsel yönü üzerinde neler etkilidir?”

\section{2. Çalışmanın yöntemi}

Nitel desendeki bu çalışma, derleme niteliğindedir. Veri toplama aracı olarak kaynak tarama tekniği kullanılmıştır. "Kaynak taraması o zamana kadar yapılmış kitap, dergi, araştırma raporu ve tezlerin taranmasını içerir" (Soyer, 2016: 21).

Kitap, makale, tez ve araştırmalarda dinlemenin, daha çok, iletişimsel yönüne dikkat çekilir. Çalışmada, alanda boşluk oluşturan bu noktanın incelenmesi amacıyla ilgili yayınlar gözden geçirilmiş ve dinlemenin dilsel yönüne ilişkin temel noktalara değinilmiştir.

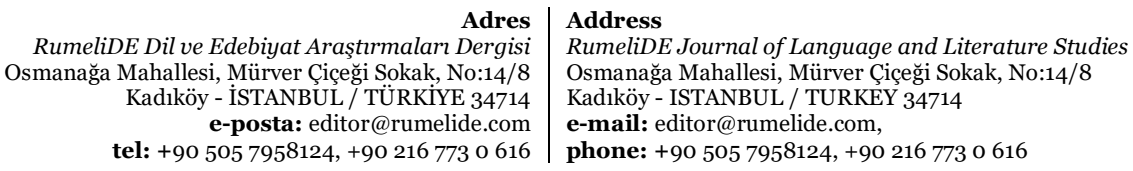




\subsection{Sinirlılıklar}

Dinleme, genellikle, izlemeyle birlikte ele alınır. İnsan birini dinlerken aynı zamanda izler; onun jest ve mimiklerini, beden duruşunu, klyafetini, oturduğu yeri vb. inceler. Sözler dinleme, beden dili hareketleri izleme ile çözümlenir. İzlemede dilsel kodlardan çok görsel kodlar devreye girer ve bu çözümleme, zihnin farklı becerilerini ve yeterliklerini ilgilendirir. Çalışma, dilsel göstergeler (kavramlar ve bunların ifadesi olan sözcükler) ve dil dışı ögelerle (ton, vurgu, durak, ritim, ezgi vd.) sınırlıdır. Bu bakımdan dinlemenin izleme ile olan bağlantısı ve izlemenin dille ilişkisi ele alınmamış; dinleme sadece karşılıklı konuşmaların, sunumların, ses yoluyla iletilen dilsel verinin çözümlenmesi bağlamında değerlendirilmiştir. Çalışmanın bir başka sınırlılığı da, dinlemenin dilsel yönünün Türkçe üzerinden incelenmesidir.

\section{Bulgular ve tartışma}

Bu bölümde, çalışmanın amacı doğrultusunda oluşturulan sorulara cevap niteliğindeki bulgulara yer verilmiş; tespit ve yorumlar tartışmaya açılmıştır.

\section{İletişim ve dinleme ilişkisi}

İnsanlar dil denilen imkânlar alanı tarafından kuşatılmış durumdadır. Bir dilde iletişim kuran konuşmacı ile dinleyici, dilin kural ve bilgisinin ötesinde bir anlaşma zemini oluşturamaz. Sözlü anlatım düşünüldüğünde bu ortam, konuşmacı ve dinleyicinin soluk aldığı bir atmosferdir. Beden dili, işaret dili ve diğer anlaşma yolları hariç tutulduğunda konuşmacı dil dışına çıkarak duygusunu ve düşüncesini yansıtamaz; dinleyici dil dışında bir araçtan faydalanarak aktarılanları anlayamaz. Düşler, düşünceler, duygular, hayaller, istekler, tasarılar ve bilgiler; dil kanalıyla bir başkasına iletilir. Dolayısıyla insan ilişkileri ve iletişim, dil sayesinde gerçekleşir.

"İletişim; duygu, düşünce ve bilgilerin akla gelebilecek her türlü yolla başkalarına aktarılmasıdır" (Baltaş, 2001: 19). Bu yollar içinde dil başta gelir. Bu nedenle dil ve iletişim iç içedir. Günümüzde birer disiplin (dil ile ilgili bilimler, iletişim bilimleri) olarak belirtilen bu alanlar, özde insan ilişkilerini anlama ve tanımlamanın sonucunda gelişmiş; kural ve çerçeveleri oluşturularak bilim dünyasının bir şubesi olmuştur. İletişimin, dil ile ilgili bilimlere göre daha yakın zamanlarda bir bilim dalı olduğu bilinmektedir.

İnsanın dile döktükleri her türlü disiplini ilgilendirir. Psikolojiden tıbba, tarihten kimyaya kadar pek çok bilim dalında, dilsel veriler ışı̆̆ında gelişme ve ilerlemeler gerçekleşir. Ancak insan ilişkileri söz konusu olduğunda dilsel veriler, dil boyutunun dışında, iletişimi sağlayan bir araca dönüşür.

Dinleme, ilk kazanılan ve hayat boyu öğrenmelerin ağırlıklı bir kısmını oluşturan önemli bir beceridir. Dinleme, bir dil becerisi olarak dil eğitimi kapsamındadır. İletişim de ilk insandan günümüze yazılı ve sözlü olarak karşılıklı anlaşmayı esas alır. Dinleme, aynı zamanda iletişimin bir parçasıdır çünkü sözlü etkileşimlerde duygu ve düşünceler dinleme sayesinde anlam bulur. Bu bakımdan dinlemenin dilsel yönünü iletişimsel yönünden ayırmak mümkün değildir. Bu ilişki, etle tırnak misali bir yakınlık gösterir.

Sözsüz mesajlar iletişim bilimi ya da psikolojiyle daha yakından ilgili iken sözlü mesajlar ağırlıklı olarak dile ait bilgi ile, dilin konuşma ve dinleme becerisi ile ilişkilidir. Kelimeler ve cümleler, sözsüz iletişimdeki beden dili davranışlarına karşılık gelir. Dinlemenin yanına izleme eklendiğinde sözlü iletişimin sözsüz iletişim ile birlikte değerlendirilmesi mümkün olur.

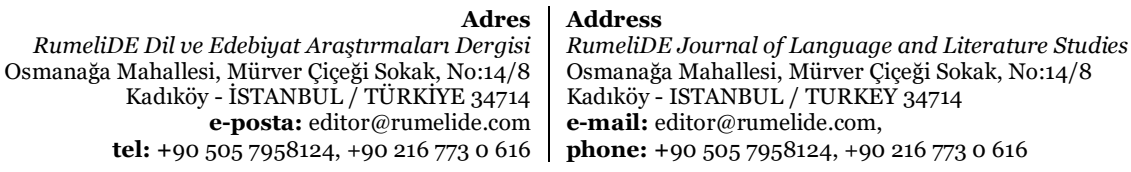


Dinlemenin farklı boyutları vardır. Dışarıdan gelen sesler duyulup anlamlandırılır ve bu sesler insan sesleri olmayabilir. Bu faaliyet de dinlemedir. Günlük hayatta sıkça maruz kalınan dinleme, diğer becerilere göre daha zahmetsiz yönetilebilir. Dinlemenin insan dışındaki canlıları, araçları, senkronize olmayan iletişimleri (video, röportaj, haber, film gibi) dinleme boyutu da bulunur. İnsan seslerini yani konuşmaları (tek taraflı, diyalog halindeki, filmlerdeki vs.) duyup algılama da dinlemedir. Dinlemeye insan üzerinden bir anlam kazandırıldı̆̆ında insanın temel anlaşma aracı olan dilin devreye girdiği görülür. Seslere bir düzen vererek sesi bir anlaşma aracına dönüştürmüş insanoğlunun, birbirini etkilemek ve yönlendirmek için kullandığı konuşma, ancak dinlemeyle anlam bulur.

İletişim, kodlar ve bu kodlara yüklenen anlam ve değerlerin ses kanalıyla iletilmesi biçiminde gerçekleşir. "Kod, bir dilsel toplulukta konuşucu (verici) ile dinleyicinin (alıcının) iletişimde kullandığı dilsel göstergeler kümesi” (İmer, Kocaman ve Özsoy, 2011: 77) olup mesaj veya ileti denilen iletişim ögesini biçimlendirir. "Mesajın içeriği anlamla ilgili iken yapısı kodlarla ve sembollerle ilgilidir" (Arslanoğlu, 2018: 27). Mesajın, kişiye göre kodlanması önemlidir. "Mesaj; alıcının eğitim düzeyi, mesleği, cinsiyeti, yaşı, ilgi ve alışkanlıklarına yönelik olmalıdır” (Gürüz ve Eğinli, 2010: 106). Alıcının özellikleri kodlamayı belirler.

Duygu ve düşünceler adeta dil üzerinden akar. Konuşmadaki seslere ve bu seslerin içinde, üstünde akan duygu ve düşüncelere dinleyicinin anlam vermesi gerekir. Bu noktada dilsel verinin ses gibi şekilsel, içerik gibi anlamsal bir özelliği bulunur. Dinleyicinin her ikisine de hâkim olması bir zorunluluktur. Sadece sese odaklanıp onları bir şeylere dönüştürmek yeterli olmaz. Bu, çocukların dili kazanırken ve konuşmalarını şekillendirirken kullandıkları taklide benzer. Dilsel veri alınır ve konuşma malzemesi olarak kullanılır. Bu taklit, çoğunlukla, anlamsal bilgiden yoksundur. Ancak belli bir yaş ve deneyimden sonra, dilsel verinin ses özelliği dışında içerik yönü de bir anlama dönüştürülür ve-taklit yine olsa daanlama, anlaşılma, bilginin kullanılmak üzere saklanması, tepki vb. devreye girer.

Dil ile iletişim birbirini tamamlar. Örneğin, özür dilemek iletişimsel bir davranıştır. Özür dilerken kullanılan dil ve üslup ise dille, dilin kullanımıyla ilgilidir. Davranış boyutuyla incelenirse iletişimsel, dil boyutuyla incelenirse dilsel yön açığa çıkar. Hem davranışsal hem de dilsel boyut öğrenilebilir. "Özür dilerim, kusura bakmayın, affedersiniz, affola vb.” kalıp ifadeler doğru yerde ve doğru şekilde kullanılmalıdır. Dinleyiciler dildeki bu tür hazır kalıpların ne anlama geldiğini bilir. Davranışa eşlik eden dil, bu bakımdan önemlidir. Olumlu davranış, olumlu ve yapıcı bir sözle desteklenirse iletişimin davranış boyutu dille tamamlanmış olur.

Kişilerin çeşitli özelliklerinin eşleştiği anlarda iletişimden üst düzey verim alınır ve dinleme de hâliyle başarılıdır. "Birisiyle iletişim kurabilmemiz için o kişinin beyninde taşıdığı şema bilgileri ile bizim şema bilgilerimizin (en az) bir bölümünün örtüşmesi gerekmektedir” (Çakır, 2014: 60). Ancak her zaman böyle bir başarıyı yakalamak mümkün olmaz. Özellikle kriz durumlarında, çatışma ve tartışmalarda dinleme etkisini yitirir. Muhabereyi muharebeye çevirmemek için iyi bir iletişimci olmak gerekir.

Dinleme etkileşim gerektirir. Konuşma esnasında, dinleyici karşısındakinin kurduğu cümleleri analiz ederken kendi cümlelerini de oluşturur, yargılarını şekillendirir. Bir anlamda iç konuşmasını yapar. Bu konuşma dışarıya yansısa da, yansımasa da bir etkileşimi gösterir.

Sözlü iletişimde konuşmalar kayıt altına alınmıyorsa, yazılı iletişimde olduğu gibi, iletilerin üzerinde durup düşünme lüksü bulunmaz. Dolayısıyla sözlü iletişim esnasında daha aktif, enerjik ve etkili bir

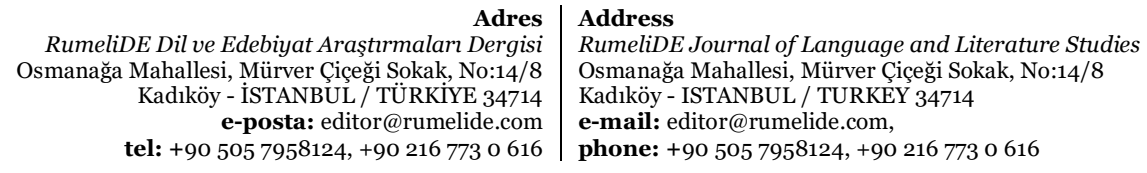


iletişim yönetimi söz konusudur. Bu bakımdan tek yönlü, karşllı̆̆ olmayan iletişimlerde, dinleyici konumundaki kişinin sunulan dilsel veriyi doğru bir şekilde anlaması gerekir.

Kişilerin karşılıklı olarak birbirlerini dinlediği, anladığı ve uygun tepkilerle doyum sağladığı dinlemeler; iletişimi güçlendiren, sosyalleşmeyi să̆layan, insanın sorunlarını gideren önemli etkileşimlerdir. Bunların başarılmasında rol oynayan dinlemenin, ağırlıklı olarak, dilsel değil iletişimsel yönüne değinilir. Saygı, nezaket, sabır, teşvik; çatışmaları önleme, paylaşım, dertleşme gibi yönleriyle dinleme, sosyal ilişkileri düzenleyen iletişimsel bir beceridir. Yine dinleyicinin güven duyulan biri olarak görülmesi, empati becerisinin takdirle karşılanması, iyi bir iletişimci kabul edilmesi gibi özellikler, dinlemenin dilsel yönünden uzaklaştığını, daha çok, iletişimsel yönün öne çıktığını gösterir. Ancak dinlemenin iletişimsel yönü de dille ilişkilidir. Dinlenilir olmanın birçok nedeni olabilir. Bunlar içinde dili etkili kullanmanın da önemli bir payı vardır. Karakter özelliklerinin yanında, bir o kadar önem taşır. İnsan, bazen, sevmediği ancak konuşmalarını kolaylıkla anladığı kişileri dikkatle dinler.

Görgü kurallarına ve nezakete uygun dinlemede dilsel değil, iletişimsel yön baskındır. Örneğin, içinde bulunulan kültüre göre yaşlı insanları ya da çocukları dinlemek bu türdendir. Burada dinleyicinin anlatılanlardan bir sonuca ulaşmasından çok, kültürel ve iletişimsel yönden belirli bir duruş içinde olması; dinlemiyor olsa bile dinliyormuş gibi davranması yeterlidir.

Değerlendirme; dilsel veriye ad vermek, iletişimi anlamlandırmak demektir. Değerlendirme gerçekleşmezse söz konusu içerik netleşmemiş olur. Bazı durumlarda söylenenler gecikmeli anlaşılır; saatler, haftalar, aylar hatta yıllar sonra bazı şeyler tekrar masaya yatıılır, tartışılır. Çünkü söz konusu değerlendirme tamamlanmamıştır.

İletişimde 4D önemlidir. Bunlar duygu, düşünce, davranış ve dönüttür. Dönütler, dinlemenin dilsel yönüne ilişkin önemli bir özelliktir. Dinleyici, ona sunulan duygu ve düşünceleri anlamlı bir şeylere dönüştürerek çeşitli davranışlarda bulunur. Dönüt, dinlemenin hem eğitim ortamlarında hem de sosyal yaşamda ölçülüp değerlendirilebilmesinin temel göstergesidir. Çünkü aradaki iletişimi beslemek için dönüte yani geri beslemeye ihtiyaç vardır. Sevdiğine bir derdini heyecanla ve telaşla anlatan kişinin, sadece ona bakan sessiz gözlerle karşılaşması ya da bir "hıhı" duyması, söz konusu iletişimi beslemez. Bunun ötesinde tepki ve onay beklenir. Dönütler bazen sözsüz, sessiz olabilir; davranış düzeyinde kalır. Ancak dilsel bir tepki söz konusu ise, bunun konuşmanın içeriği, bağlamı ve etkileri ile ilgili olması bir zorunluluktur.

Bir insanı dinlerken o insanla oluşan mesafe, kıyafet, aksesuar, koku, mekân kullanımı, mimikler, jestler vb. dilsel olmaktan çok, iletişimsel özelliklerdir.

Dinlemenin içinde bulunduğu sözlü iletişimin dışında, iletişimin bir de yazılı boyutu vardır.

\section{Dinleme neden bir dil becerisidir?}

İnsan; hayatı öğrenmeye, hayatı tatmaya anne karnında başlar. Karanlık bir ortamda, henüz dünya ve insanlarla iletişime geçmemiş, dışarıdan gelen sesleri algılamaya çalışan bir insan yavrusu düşünüldüğünde bebeğin dinlemede dilsel yönü kullandı̆̆ı; dil denilen düzenli ve sistemli bir dizge aracılı̆̆ıyla, tutarlılık gösteren sesleri algıladığı anlaşılır.

Dinleme eğitimi ile ilgili araştırma, çalışma ve yayınların önemli bir kısmını iletişim bilimine ait teknik bilgiler oluşturur. Oysa iletişimi oluşturan unsurları meydana getiren, temelde dildir. İnsanı öteki

\footnotetext{
Adres | Address

RumeliDE Dil ve Edebiyat Araştırmalar Dergisi $\quad$ RumeliDE Journal of Language and Literature Studies Osmanağa Mahallesi, Mürver Çiçeği Sokak, No:14/8 $\quad$ Osmanağa Mahallesi, Mürver Çiçeği Sokak, No:14/8 Kadıköy - ÍSTANBUL / TÜRKIYE 34714 Kadıköy - ISTANBUL / TURKEY 34714 e-posta: editor@rumelide.com e-mail: editor@rumelide.com, tel: +90 505 7958124, +90 2167730616 phone: +90 505 7958124, +90 2167730616
} 
varlıklardan ayıran özelliklerden biri olan dil, iletişimin temelidir. "İnsanlar duygu ve düşüncelerini sözlü ve yazılı olarak anlatmak istediklerinde ortaya dil dediğimiz semboller çıkmaktadır” (Kayaalp, 1998: 2).

Dinlemenin konuşmayı meydana getirmesi dilsel yönünü ortaya koyan bir başka kanıttır. Sese, konuşmaya, standart dilin kalıplarına yansıyan ve konuşmacıyı bu kalıpları kullanmaya zorlayan dil; mantı̆̆ını dinleyicilere duyurur. İnsan; dilin vurgu sistemini, konuşma akustiğini, tonlama ve ünlem bilgisini ancak dinleme ile algılayıp anlayabilir. Dil kabına ya da kalıbına dökülen kültürü de ancak dille açığa çıarmak mümkündür.

İnsanlar günlük hayatta genellikle hazır kalıpları ve klişe ifadeleri kullanırlar. Bunlar dilin önemli bir kısmını oluşturur. Selamlamalar, ricalar, nezaket ifadeleri, sitemler, başlangıç sözleri, temenniler vb. iletişimde insanların sıklıkla başvurduğu hazır dil malzemesidir.

Dinlemenin dilsel yönüyle neler doğrudan ilişkili değildir? sorusunun cevabını da vermek gerekir. Uzun süre dinlemek, kısa süre dinlemek; kişinin ilgisi, motivasyonu, zaman yönetimi, hareketliliği; dinlemede ön yargl, empati, sabır, nezaket...

\section{Dinleme ve diğer dil becerileri}

Dinleme, bir dil becerisidir ve diğer dil becerileriyle ilişkilidir. Dinlemenin diğer dil becerilerinin temelini oluşturduğu bilinmektedir. Dinleme, yapının temelini kurar ve diğer dil becerileri bu yapının üzerine inşa edilir. Konuşma dinlemeyle, yazma ise okumayla kazanılır.

Dinleme ve okuma, anlama başlığı altında birleşir. "Okuduğunu ve dinlediğini anlama becerileri birbirine çok benzeyen süreçlerdir” (Özbay, 2009: 59). Dinlenileni anlayıp çözümleme, okuduğunu anlayıp çözümleme gibi dilsel bir etkinliktir. Her ikisinde de benzer süreçler vardır ve aynı mekanizmalar işletilir. Dinlemede sesler, yazıdaki harfler gibi beyne ulaşır ve bütünleştirilerek bir anlama dönüştürülür. Dinleme, bir anlamda, sesler üzerinden görünürlük kazanan metinlerin incelenmesidir.

Dinleyici, sesli okumaları dinlerken okumaya benzer bir faaliyette bulunur. Bu tür bir dinleme; işiterek, dinleyerek yapılan bir okumadır. Dile ait veriler alınıp işlenir. Konuşulanları dinlemeden farklı olarak sesli okumaları dinleme, dilsel verileri gölgeleyen veya destekleyen sözsüz unsurların aradan çekilmesinden dolayı, dinleyiciye daha net bir çözümleme imkânı sunar.

Ön bilgilerin okumada kullanımı, dinlemede de görülür. Kişinin geçmişteki öğrenmeleri, sözcük dağarcığı, bilgisi vb. dinleme anında bağlantılar kurmasına, çağrışımlar oluşturmasına imkân tanır. "Beceriyle dinlemek, konuşmacının söyledikleri ile önceden bu konuyla ilgili kendi bildikleriniz arasında bağdaştırmalar yapabilmek demektir" (Shafir, 2003: 284). Dinleyici, dinleme sırasında, konuşanın cümlelerine sözcük ekler, konuşma bütünlüğünden sözcük çıarır, Türkçenin yapısı gereği cümlenin sonuna gelen yüklemleri/eylemleri tahmin eder.

Karşılıklı diyaloğun her bir susuşla, nefeslenme ile bloklanan bölümü, aslında, birer metin parçasıdır ve okumada olduğu gibi, bu bölümleri birer paragraf ya da cümle topluluğu olarak anlamak gerekir. Dinleyici-okurken gözün satır üzerinde yaptığı sıçramalar gibi-kulağı ve zihniyle ses üzerinden akan bilgiyi ögelerine ayırarak, bölümleyerek, anlam duraklarıyla anlamaya ve yorumlamaya çalışır. Dinlemenin bazen kitap okumanın lezzetine ulaştığı söylenebilir. Özellikle güzel ve etkili konuşan

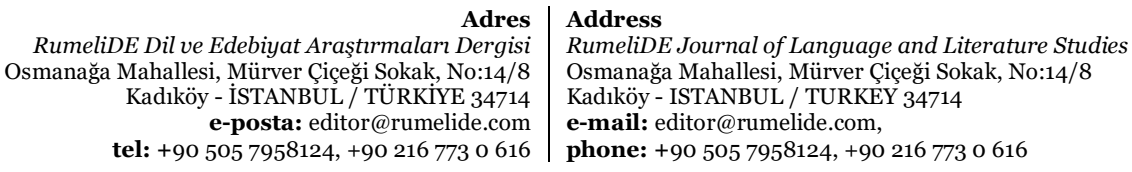


kimselerin konuşmalarını dinleyen; bu konuşmalardaki dil kullanımını, ritmi, ana dilinin estetik ve ahengini hisseden dinleyici; Yahya Kemal'in "Bu dil ağzımda annemin sütü gibidir." sözüyle ebedileştirdiği hazza ulaşabilir.

Okuma eğitimine harflerden, dinleme eğitimine seslerden başlanır ve cümlelere, söyleme, yani metne uzanılır. Konuşma ise havaya çizilen dünyadır; bir anlamda metni sesle, sözle oluşturma ve yazmadır. Dinleme, konuşmayla birlikte ele alınır. Çünkü dinleme, konuşmanın oluşmasını sağlar. Konuşma, bir anlamda, dinlemenin doğal sonucudur. "Konuşma; tek yanlı, kendi içinde başlayıp biten bir şey değil, dinleme ile iç içedir” (Çongur, 1999: 85).

Dinleme ile konuşmanın sırt sırta verdiği bilinir. Her ikisi de anlamanın ve anlaşmanın aracıdır. Dinleme olmadan konuşma, konuşma olmadan dinleme olmaz. Konuşma, dinlemenin başlangıcı ve lokomotifidir. Bir konuşma faaliyeti sonrasında dinleme becerisi ve eyleminden söz edilebilir ve dinleme, beraberinde konuşmayl getirir. Konuşma, sesi söze; dinleme, sözü anlama dönüştürmedir.

İletişimde dilsel kalabalığa aldanmamak, anlamı inşa eden dil dışı (parçalar üstü-prozodik) ögelere (ton, vurgu, durak vb.) odaklanmak gerekir. Yazılı dilde olduğu gibi, konuşmada da yüzey yapıdaki (sesteki) verilerden çok derin yapıdaki anlamlar ön plana çıar.

Zengin kelime hazinesine sahip bir dinleyici, konuşmay kelimelere takılmadan ve kesintiye uğramadan takip edebilir, konuşmacıyla eş zamanlı bir şekilde aynı anlamı birlikte oluşturabilir; bu süreç kelime hazinesi gelişmiş bir okuyucunun, metni rahat ve akıcı okumasına benzer.

\section{Dinlemede dilsel verinin önemi ve etkileri}

İletişimde kullanılan dilsel veri, dinlemeyi etkiler. Ses, hece, sözcük, sözcük grubu, cümle, söylem gibi değer ve anlam ifade eden yapılar dışında; konuşma özellikleri ile konuşmada yaşanan problemler (dil sürçmeleri, ilişkilendirme hataları, çağrışım uyuşmazlıkları, örneklerin tutarsızlı̆̆ı, lafı dolandırma, sadede gelememek, konudan sapma, gereksiz tekrarlar, sesletim sorunları, vurgu ve tonlamaya karışmış ilişkisiz duygular, yanlış sözcük seçimi, geriye dönüşler, tökezleyen bir dil, heyecanlı konuşmalar, abartma...) de dinlemede etki sahibidir.

Dinleme sürecinde, dilsel kodlara eşlik eden diğer ögelerin (ton, vurgu, ritim, ünlem, ahenk, ezgi, hız, durak, tını, nefes, konuşma temposu, ulama, sükût, yumuşaklık, sertlik, süre, acele, sakinlik, aksan...) de dikkatle çözümlenmesi gerekir. Kelimeleri, adeta gölgeleri gibi takip eden bu dil ötesi ögelerin konuşmada nasıl kullanıldığına odaklanmalıdır. Bazen sadece derin bir iç geçirme iletişimsel olabilir; bir saatlik bir konuşma, sadece bir ünlem (tüh tüh, vah vah, evet!, yaa!) ile açıklığa kavuşabilir, bazı sözcükler zihne atılmış birer kanca gibi takılıp kalır. Kelimelerin, bir duygu veya düşüncenin yüzde kaçını ortaya koyduğu tartışılır ancak bazen bir ifade (Hayır!) destan değerindedir. Bu bakımdan dinleyicinin dilsel ifadeleri uygun şekilde birleştirmesi, dilin yapı ve parçaları arasında doğru bağlantılar kurması, konuşmacıy kullandığı dil ve dil ötesi ögelerle ilişkilendirmesi gerekir.

Konuşmaya karışan duygular (kin, öfke, nefret vb.; sevgi, sempati, hayranlık vb.) da dinlemeyi, dil malzemeleri ve dil dışı ögeler kadar etkiler. Hatta kelimelerle birlikte akan ve kelimelerin önüne geçen duyguların da iletişim sırasında dilsel rollere sahip olduğu söylenebilir.

Sesler, herkesin üzerinde anlaştığı "kodlar" olarak kendini gösterirken, kavramlar tam olarak anlamını bulmayan, herkesin çok farklı değerler yüklediği dilsel araçlardır. Satranç oyununu oluşturan taşların

\footnotetext{
RumeliDE Dil ve Edebiyat Arasturmaları Adres $\mid$ Address

RumeliDE Dil ve Edebiyat Araştırmaları Dergisi $\quad$ RumeliDE Journal of Language and Literature Studies

Osmanağa Mahallesi, Mürver Çiçeği Sokak, No:14/8 Osmanağa Mahallesi, Mürver Çiçeği Sokak, No:14/8

Kadıköy - ÍSTANBUL / TÜRKIYE 34714 Kadıköy - ISTANBUL / TURKEY 34714

e-posta: editor@rumelide.com e-mail: editor@rumelide.com,

tel: +90 505 7958124, +90 2167730616 phone: +90 505 7958124, +90 2167730616
} 
neyden yapıldı $\breve{g}$, fiziksel özellikleri bir yere kadar önemlidir. Önemli olan o taşların oyun içindeki görev ve fonksiyonlarıdır. Dolayısıyla seslerin ne olduğu veya sayısından çok, bu seslerin kombinasyonları ve dilde aldığı görevler önemlidir. Ancak bunlardan da önemli olan, sözcüklerin ötesindeki-belki de içindeki-anlamdır. "Hayatımızdaki duygusal kayıpların birçoğu sadece kelimelere, yani aslında mesajın ayak izleri ve gölgesi olan sözcüklere dikkat etmekten kaynaklanır ve biz buna 'dinleme' adını veririz" (Shafir, 2003: 180). Bu bakımdan mesajların anlamsal ve sembolik yönleri, sözcüklerin sözlük anlamları ve duygusal değerleri ayrı ayrı incelenmelidir.

Sözcükleri ilk anlamlarıyla, sözlük anlamlarıyla değerlendirmek doğru olmaz. Özellikle sözlü iletişimdeki tonlama denilen dil dışı unsur, sözcükleri sözlük anlamlarının dışında, farklı anlamlara ulaştırır. Sözlükte "evet”, “evet” anlamına gelir ancak sözlü iletişimde "evet!” derken onlarca anlam oluşabilir. "Bir anlamda tonlama, değişik ses renkleri kullanarak konuşmayı bestelemektir" (Maviş, 2006: 47).

Dinlemenin dilsel yönüne değinirken sükûta, sessizliğe de pay vermek; zaman zaman sükûtu dinlemek, sessizliğe ve eslere de gerekli anlamı yüklemek gerekir. Sükût, en az dilsel ögeler kadar bir arka plana ve anlam kataloğuna sahiptir. Yeri geldiğinde sükûtla iletişim kurulur ve dile dökülebilecek duygu ve düşüncelerin yerine sükût daha etkili bir araç olur. Sükût, sessiz bir konuşmadır, özel bir anlaşma zeminidir, bir anlamda sessiz düşünmeleri dinlemektir.

Boşluk pek sevilmez, korkutucudur. Konuşmacı, bu boşlukları doldurma telaşıyla asalak seslere (eee, 111, mmm...) başvurur. Aynı zamanda gaflar ve tartışmalı sözler de bu boşluklar sonucu ortaya çıkar. İletişimde boşluğa, bazen boşluk olma hakkını bilinçli bir şekilde tanımak gerekir.

Dinlemede göz teması olmalıdır. Dilsel veriye odaklanıp çözümleme yapmak her ne kadar kulağın ve beynin işi gibi görülse de konuşan kişinin büründüğü hal ve yaptığı hareketler, dilsel veriyi şekillendirir, netleştirir. Bu çalışmada ele alınmasa da beden dili okumaları, dinlemenin dilsel çözümlemeleriyle el eledir.

Kelimeler metinle anlam bulur, metin içinde kendini gösterir. Metin, kelimeyi korur ve yaşatır. Metin bazı durumlarda bir cümle düzeyindedir. Ancak genellikle daha fazlasıdır.

Dinlemenin, anlık başvurulabilecek bir sözlüğü yoktur. Dilsel verideki bilinmeyen kelime oranı dinleyiciyi zorlar. Bağlamdan çeşitli anlamlar çıkarılsa da, sözlük gibi başvuru kaynaklarına bakmak mümkün olmaz. Bu nedenle dinleyici, bağlamı iyi takip etmeli ve bilmediklerini bildiklerinden yola çıkarak tahmin edebilmelidir.

Konuşmada ifadeler, aslında birer kap veya mahfaza gibidir. Bunların içine ne konulduğu, hangi anlamın yerleştirildiği önemlidir. Bu kutu veya paketlere yerleşmiş öz, ancak bağlam dikkate alındığında çözülür ve anlaşılır.

Konuşmacının sözcüklerden çok sözcük gruplarını kullandığı konuşmalar, nitelik açısından iyi olan konuşmalardır. Bu durum, anlaşılırlık bakımından, muhatabının da aynı oranda iyi bir dinleyici olmasını gerektirir.

Sözlü iletişimde, hem alıcı hem de verici kelime hazinesi harekete geçse de, ne dinleyici ne de konuşmacı dile ait veri tabanının tamamını kullanır. Anlık karşılaşmalarda, her iki taraf bildikleri ve bilebildikleri oranında konuşur, anlaşır.

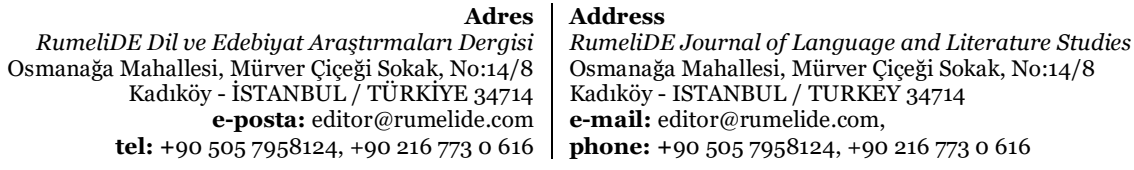


Sözcükler etki altına alır, adeta hipnotize eder. Örneğin; övgü dolu, motivasyonel sözler dinleyiciyi etkiler, harekete geçirir, yönlendirir. Böyle anlarda konuşmacı sözcükleri değil, bir anlamda, duyguları sesletir. Konuşmacı bazen insanı teskin eden sözcükler (sükûnet, huzur, rahatlık, esenlik, gevşeme, derin nefes vb.) kullanır. Bu kelimeler, dinleyici üzerinde fiziksel, fizyolojik ve psikolojik etkiler oluşturur.

Ortak kelimelerin olmayışı, argo kullanımı veya jargon; dinleme yeterliğini dilsel açıdan zorlar. "Konuşmalarda kullanılan jargon, açık bir konuşmanın önünde engeldir. Dinleyiciler açısından jargon derin bir güvensizlik üretir” (James, 1999: 109-110; akt. Kıymaz, 2018: 140). Örneğin, tıp jargonundaki "eks oldu" ifadesi tıp veya sağlıkla ilgili bazı bilgilerden yoksun dinleyici için bir anlam ifade etmez.

Türkçenin matematiksel özelliği ve ana dili olarak kolay öğrenilip yönetilebilmesi, önemli bir avantajdır. Sözlü veya yazılı dilde, akışta gelecek sözcük ve cümleyi, sözcük kalıplarını tahmin etmek zor değildir. Dile hâkim bir dinleyici, konuşma akışında gelecek eylemleri/yüklemleri kolayca belirler.

Her metinde olduğu gibi, her konuşmada da anahtar kelimeler bulunur. Konuşmanın bütünü içinde ana fikri destekleyen, sık tekrar eden ya da eş ve yakın anlamlılarıyla verilen, konuşmanın başında veya sonunda görülen, dikkat çekmek amacıyla kullanılan bu ifadeler, konuşmanın özünü yansıtan ipuçlarıdır. Dikkatli ve ilgili bir dinleyici bu tür ifadeleri kolayca yakalayabilir. "Bilhassa kullandığı anahtar kelimeler konunun ana hatlarını vermesi bakımından önemlidir. "Her şeyden önce” önemlisi", "bu nedenle", "sonuç olarak", "özetlemek gerekirse”, "diğer taraftan da önemlisi”, “öncelikle”, "bundan dolayı", "birincisi”, "ilk olarak" "bunun yanında", "bununla birlikte", "aksine”, "tam tersine” vb. anahtar kelimeler temel taşlarını vermesi açısından önemlidir” (Kardaş, 2018: 159).

Dil bilgisi bakımından sağlıklı olmayan; tashihe muhtaç, anlatım bozuklukları ve dil yanlışları içeren dilsel ifadeler; anlam kayılarına neden olur. Dil bilgisinin her bir bölümü, dinlemede dilsel malzeme olarak açığa çıkar. Dinlemenin dilsel yönünün, aynı zamanda o dilin dil bilgisel yönünü de kapsadığı bilinmektedir. Yan yana dizilmiş ifadeler hiçbir dilde anlam için yeterli olmaz. Dil kullanımı; o dilin kuralları, dil bilgisi ve diğer yapısal özelliklerinden etkilenir.

Dile sızan, dille verilmek istenen ana fikrin kaçırılmaması ve anlaşılması gerekir. Ana fikir, sadece bir cümlenin içinde yer alabileceği gibi, 10 dakikalık bir konuşmanın tamamında veya sadece bir kelimede bile gizlenebilir. Kıssadan hisse gibi bir bölüm aramak doğru olmayacaktır ancak tekrarlar önemli ipuçları sunar. Nasıl ki bir kitabın tamamının altı çizilemezse dinlemeye konu olan bir konuşmanın tümü önemli olmaz. Arada doldurma sözcükler, uygunsuz veya gereksiz bağlaçlar, dolgu sesler, sükût vb. söz konusudur.

Sunulan dilsel içerik bazen kelimelerle ilişkisiz, kelimelerin çok ötesinde, farklı anlam ve yorumları gerektiriyor olabilir. Bu durumda dinleyicinin, dilsel veriyi olduğu gibi değil, kodların dışında, ima ettikleri, çağrıştırdıkları üzerinden kavraması ve değerlendirmesi gerekir.

Karşıdakinin sözcüklerini ve o sözcüklerin derinliğini anlamak; bunları doğru yorumlamak ve konuşmaya uygun cevaplar hazırlamak kolay değildir. Bilinmelidir ki dilin gösterdiğinden fazlasını gizleme, üstü kapalı anlatma hatta şifreleme özelliği vardır. Dolayısıyla muhatabı dinlerken her şeyin hemen anlaşılmayacă̆

Türkçedeki ama, fakat, ancak vb. bağlaçlar; sıralı ve bağlı cümlelerde, cümlenin ilk yarısında dile getirilen duygu veya düşünceyi anlamsız kılabilir. Bir dizi olumlu açıklamadan sonra ama ile başlayan

Adres | Address

RumeliDE Dil ve Edebiyat Araştırmalar Dergisi $\quad$ RumeliDE Journal of Language and Literature Studies

Osmanağa Mahallesi, Mürver Çiçeği Sokak, No:14/8 Osmanağa Mahallesi, Mürver Çiçeği Sokak, No:14/8

Kadıköy - ISTANBUL / TURKIYE 34714 Kadıköy - ISTANBUL / TURKEY 34714

e-posta: editor@rumelide.com e-mail: editor@rumelide.com,

tel: +90 505 7958124, +90 216773 o 616 phone: +90 505 7958124, +90 2167730616 
bir cümle, olumsuz bir anlam oluşturabilir. "Seni seviyorum ama..." Tabii her durumda bu bağlaçlar olumsuz bir niyeti veya amacı ortaya koymaz, bazen tersi olur. "Beni çok kırıyorsun fakat yine de seni seviyorum.” Dinleyici neyin ön plana çıarıldığına dikkat etmelidir.

İkili değil, çoklu diyaloglarda, konuşanlar kendi aralarında bağlam oluşturup dili şifreleyebilir ve sadece kendi anlaşmaları için bir koridor açabilir. Bu tür durumlarda kelimeler bilinen anlamların dışında, oldukça özelleşmiş yapılara dönüşür.

İnsanların iletişimsizlikten korktukları için iletişimi artırma gayreti sonucunda konuşmalar, gereğinden fazla uzayabilir ve konuşma bütününde ilgili, ilgisiz; çelişkili ve tutarsız birçok şey bulunabilir. Bu durum anlaşılmanın önünde bir engel oluşturur.

Sözlü anlatımda ifadeler, bazen, yazıldığı okunmaz, sesletildiği gibi anlaşılmaz. "Ne yaptın!” Bir soru değildir. Uygun vurgu ve tonlama ile "Bunu nasıl yaptın!" anlamına gelebilir. "Senin ne kadar dürüst olduğunu bilmiyor muyum?” olumlu cevabın, sorunun içinde gizlendiği bir açıklamadır. "Aman ne hoş! Güzel bir sürprize sevinmeyi de ifade edebilir, ısırıcı ve müstehzi bir eleştiriyi de” (Porzig, 1985: 7). "Peki!", "Tamam!" ifadeleri kuvvetli bir muhalefet, onaylamama ve kızgınlık olabilir. "Farz edelim ki, dediğin olsun...” cümlesinin inandırıcılık oranı düşüktür. Bir cümlede -ebilir rastgele kullanılmamış olabilir. Geç gelen çocuğuna "Neredeydin?" diyen bir baba, öfke veya sitemini ortaya koyarak "Neden bu kadar geç kaldın?” demiş olabilir. Babanın, mekânı sorarken zamanı kastetmesi dilin şifreli yönünü örneklendirir. Duyguya bağlı olarak sözcüklerin telaffuzu değişir. Konuşan, sözcükleri heceleyerek (Yapa-cak-sın!) öfke ve uyarısını yansıtır. "Kesin sözcükler ve 'meli, malı' şeklindeki ifadeler sizinle konuşan kişinin dinleme isteğini kolayca kaçırabilecek kritik sözcüklerdir” (Shafir, 2003: 250). "Bilmiyorum ya da emin değilim kelimelerini yanlış anlaşılmalara mahal vermeyecek şekilde kullanmalıdır” (Işık, 2013: 98). Dilde anlam, genellikle, kendini farklı bir şekilde göstermekte ve ifadelerin arkasına gizlenmektedir.

Günlük hayattaki konuşmaların önemli bir kısmının anlamlı, gerekli ve hedefi vuran konuşmalar olmadığı bilinir. Etkili ve yapıcı konuşmalarda bile doldurma bölümler olduğu düşünülürse anlaşmak için dildeki çarpıcı ifade veya tavırlara dikkat etmek gerektiği anlaşılır. Bir maninin nasıl ki ilk iki dizesi doldurma, asıl dile getirilmek istenen sonraki dizelerdeyse (son iki dizede), benzer şekilde, iletişimde de konuşmaya giriş yapıldığını gösteren doldurma kısımlar vardır. Bu hazırlık ve ısınma, asıl konuya giriş için uygun zemini hazırlar.

İnsanın bellek kullanımı sınırlıdır. Bu nedenle kısa cümleler daha iyi hatırlanır. Türkçenin girişik birleşik cümle, şartlı ya da bağlaçlarla kurulan cümle yapıları yazmada olduğu gibi konuşmada da anlamayı etkiler. Yine fiilimsilerle uzatılan cümleler anlaşılırlığı zorlar. Bu noktada nicelik, nitelik kadar önemlidir.

\section{Konuşmacının, dinleme ve dinleyici üzerindeki etkisi}

Konuşmanın içeriği kadar konuşmacının dil kullanımı ve özellikleri de dinlemeyi etkiler. "Konuşmayı başlatan ve genellikle de uzun bir süre sürdüren kimsenin, karşısındaki kişi tarafından etkili bir şekilde dinlenilmesi için bazı yeterliklere sahip olması gerekir" (Emiroğlu, 2013: 281). Konuşmacı; duygu, düşünce veya bilgileri açık ve net, iyi bir diksiyonla aktarmalı; dinleyici de sunulan dilsel veriyi yerli yerine koyarak gerekli anlamı oluşturmalıdır. Bu karşllıklı çaba, dinleme sürecinden üst düzey verim alınmasını sağlar.

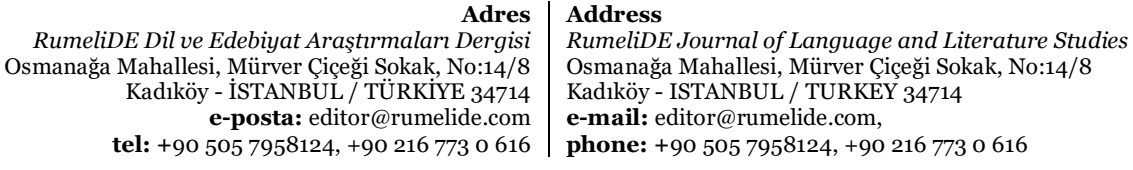


Hedefe dönük oluşturulmuş ifadeler, seviyeye uygun bir üslup, imalardan arınmış cümleler, basit ve dolaysız iletiler, arı duru bir dil, somutlaştırmalar, güçlü ve kalıcı sözcükler, etkili benzetmeler, uygun örnekler, dildeki bazı hazır kalıplar, etkili diksiyon, kısa cümleler ve öz anlatım; etkili ve başarılı dinlemenin temel formülüdür. Konuşmacının bu noktadaki rol ve sorumluluğu üst düzeydedir.

Yoğun mecaz, espri ve kinayeler, kelime oyunları içeren ifadeler, felsefi yargı ve değerlendirmeler vb. ortaya konulmuyorsa dinlemeyi başarılı kılmak için konuşmanın mümkün olduğunca sadeleştirilmesi, uygun sözcük seçimleriyle anlaşlır hale getirilmesi gerekir. Bu özellik, dinleme sürecinin konuşmacıya bakan yönüdür.

Karşılıklı konuşmalarda sadece konuşmacı yoktur, konuşmacı aynı zamanda dinleyicidir. Hatta konuşan kişi, onu dinleyen kişi veya kişiler kadar iyi bir dinleyici olmalıdır. Az söyleyip çok dinlemeyi düstur edinen, lafını bilen bir konuşmacı, dinleyiciye önemli faydalar sağlar.

Konuşmacının niteliği ve dili etkili kullanma noktasındaki verimi; dinleyiciden bağımsız, dinleyicinin müdahale edemediği bir özelliktir. Dinleyici, konuşmacının dili kullanma yeterliğine tabidir. "Dinleyici pasiftir, kendi tutkularının etkisinde kaldığı gibi hatibin de etkisinde kalır” (Meyer, 2009: 11). Ancak bu, bir çift sözü bir araya getiremeyen bir konuşmacının anlaşılamayacağı anlamına gelmez. Bazı durumlarda dilsel sunumdaki parçalar, konuşmanın bütününe ait fikir verebilir.

Konuşmacı, her durumda, açı bir iletişimi tercih etmeyebilir. Bazı durumlarda dilsel veriyi sansürleyebilir, bağlamından koparabilir, kısaltabilir, çarpıtabilir, abartabilir veya değiştirebilir. Dilinin altındaki baklayı çıkarmak istemeyen, lafı adeta çiğneyen, dile getirirken aslında düğümleyen, bir araba laf edip de bir şey söylemeyen, iğneli ve alaylı ifadelerle dokundurmalarda bulunan, kızım sana söylüyorum gelinim sen anla düşüncesiyle kinayeli ve dolaylı anlatımları tercih eden, üst perdeden veya üstü kapalı konuşan konuşmacılar dinlemeyi olumsuz etkiler.

Her dil, sistemiyle (dizge-edinç) mükemmele yakındır. Ancak onu kullananların dildeki performansları (edim), dilin kusursuzluğunu zedeler. Bu, doğal bir şeydir. Her durumda insanın karşısına nitelikli konuşmacılar çıkmaz. Konuşmacı dili döndüğü oranda kendini ifade eder. "Kimi konuşurlar dilsel olanakların tümünden yararlanmayıp yalnızca bir bölümünü kullanmakta, düşüncelerini mantıksal ilişkiler içinde anlatamamakta, iletişim sırasında sık sık dil dışı imlere başvurarak dar koddan yararlanmaktadırlar" (İmer, Kocaman ve Özsoy, 2011: 80). Bu tür konuşmacıların dinleme ve dinleyici üzerindeki etkisi zayıf olacaktır.

Tekdüze bir anlatım, bir anlamda, dilsel verinin laneti, illetidir. Konuşanın; önemli bilgileri monoton, coşkudan yoksun, tonlamanın doğru kullanılmadığı bir anlatımla sunması halinde dilsel içerik dinleyiciye etkili bir şekilde ulaşamayacaktır. Eskiler “İyi söz dinletir, kötü söz esnetir." derler.

Yüklemlerle birlikte tükenen, cümlenin sonuna doğru-sönen bir balon gibi-sesi, nefesi kaybolan bir konuşmacı, dinleyici üzerinde istediği etkiyi bırakamaz. Benzer şekilde, boğumlamanın tam olarak gerçekleşmediği, fazla hızlı, gereksiz ulamaların olduğu konuşmalar da dinleyiciyi anlama noktasında zorlar.

Dinleme ve dinleyici üzerinde etki sahibi olan konuşmacılar, birbirinden yüz seksen derece farklı karakter ve özellikte olabilir. Cetvelin bir ucunda ağzına kira istercesine dilinin ucuyla konuşan, ağzından cımbızla laf alınan az konuşanlar; bir diğer ucunda çenesi kuvvetli, dili açılıp çözüldüğünde durdurulamayan, her ortamda nutuk çeken, kısa kesmeyi bilmeyen çok konuşanlar vardır. Arada ise ağzı

Adres $\mid$ Address

RumeliDE Dil ve Edebiyat Araştırmalar Dergisi $\quad$ RumeliDE Journal of Language and Literature Studies Osmanağa Mahallesi, Mürver Çiçeği Sokak, No:14/8 $\quad$ Osmanağa Mahallesi, Mürver Çiçeği Sokak, No:14/8 Kadıköy - ISTANBUL / TURKIYE 34714 Kadıköy - ISTANBUL / TURKEY 34714 e-posta: editor@rumelide.com e-mail: editor@rumelide.com, tel: +90 505 7958124, +90 2167730616 phone: +90 505 7958124, +90 2167730616 
laf yapan, iyi ve yerinde konuşanlar kadar; istediği halde iki sözü bir araya getiremeyen, kem küm eden, sözü ağzında geveleyen konuşmacılar bulunur. Bütün bu konuşmacı tipleri dinleme etkinliği üzerinde söz sahibidir.

Doğrudan iletişimin sıcaklığı ve enerjisi içinde dinleme, daha fazla önem ve anlam kazanır. Fakat bu durum, hataları da beraberinde getirir. Örneğin, diyalog halindeyken karşlıklı enerji akımını, hızı, sözcüklerin tam olarak ne çağrıştırdığını o an anlamlandırmak ve süreci yönetmek kolay olmaz. Oysa bir radyo veya televizyon yayınını dinlerken yüzde yüze varan bir performansla dinleme gerçekleşebilir.

Bir diğer nokta da konuşmacının kimliğidir. Konuşmacının kim olduğu, sözcükleri kadar hatta onlardan da fazla etki bırakır. Bu bakımdan, insan ilişkilerinde ifadeler ve anlatım; konuşmacının bıraktığı izlenimi aşamaz. İster istemez söze değil, söyleyene bakılır.

Konuşmacının kişilik özellikleri dinlemeyi etkiler. Bazı konuşmacılar her zaman heyecanlıdır ve bu heyecanları konuşmalarına yansır. Böyleleri çok şey söylemek isterken bir şey söyleyemez, dili tutulmuş bir hal alır. Hızlı konuşan konuşmacılar kadar yavaş konuşanlar da dinlemeyi olumsuz etkiler. Bazıları ise sözcükte tasarrufludur. Kelime israfında bulunmaz. Bazıları da bir kelime veya cümleyle ifade edilecek düşünceleri birkaç cümleyle dile getirir. Bütün bunlar, dinleme üzerinde etkiler oluşturur ve dinleyicinin, konuşmacı tercihinde bulunmasına neden olur.

Konuşmacının üslubunu kavramak, konunun özünü anlamak sayılır. İnsanların anlatış tarzları birbirinden farklıdır. Kelimeler, cümleler üslup içinde anlam kazanır. Konuşmacının üslubu ve kullandığı teknikler iyi olduğu oranda dinleme sürekli ve yararlı olur. "Etkili ve amacına uygun bir konuşma yapılabilmesi için dinleyicileri rahatsız etmeyecek, onların ilgilerini konuya toplayacak bir üslup takınılması önemlidir” (Temizyürek vd., 2007: 254).

Ana dili içinde binlerce, on binlerce dil vardır. Bu diller varyant veya yöresel dil değil, insanların seviye ve algısına göre biçimlenen ve idiolect (bir dilin belli bir bireyde aldığı biçim) denilen (Vardar, 2002: 45) dil kullanımlarıdır. İnsanlar, aynı ana malzemeleri kullansa da oluşan anlamlar farklıdır. Örneğin, küçük bir çocukla konuşurken standart veya resmî bir Türkçe kullanılmaz.

Kullanılan dilde niceliksel farklılıklar da bulunur. "Eğitimli insanlar, yazılı ve sözel dilde eğitimsizlere göre; yaşı daha ileride olanlar daha genç olanlara göre daha fazla kelime kullanır" (Brysbaert vd., 2016: 1116). Kişisel özellikler dil kullanımını biçimlendirir.

Yaşla birlikte, deneyimin artmasıyla insanlar konuşmalarında sözcük seçer, tek seferde anlaşılmasını istediği ifadeler kullanırlar. Ancak çocuk ve gençler, bu noktada daha duyarsız ve kayıtsız olabilir, onlar için anlaşılırlık ikinci planda kalabilir. Genellikle dolaylı, hata dolu, abartılı ve birçok dil yanlışı içeren konuşmalar görülür. Gençlerin hızıyla yetişkinlerin anlaşılma kaygısını harmanlamak uygun olacaktır.

Konuşmacının dil ötesi birimleri (vurgu, ton, durak, süre, ezgi, ulama vs.) nasıl kullandığı kriminal çözümlemelerle gerçeğe yakın bir şekilde ortaya konabilir. Ancak günlük hayatta sıradan bir dinleyicinin, konuşanın konuşma üzerindeki dil ötesi etkilerini tam olarak çözümlemesi beklenemez.

Konuşmacı konuşmaya kendini kaptırdığında dinleyicinin söylenenleri ne oranda anladığını düşünemez. Konuşmanın sarhoş edici etkisiyle konuşmasını kesintisiz bir şekilde sürdürür. Böyle zamanlarda konuşmaya uygun bir şekilde ara vermek gerekir. "Önemli bir cümleden önce ya da sonra

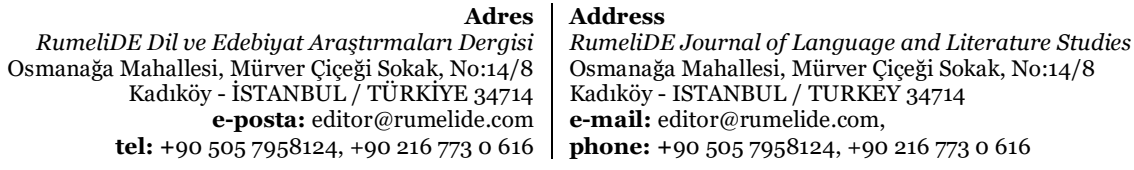


bir süre es vermek, konuşmanın hipnotik monotonluğunu kırmak bakımından da faydalı olur” (Shafir, 2003: 300). Konuşmacının bu tür bir iradeye ulaşması, iletişimi etkili kılar.

Konuşmacının dilsel veri, dinleme ve dinleyici üzerindeki etkileri düşünüldüğünde ve bu etkinin insan ilişkilerini düzenleyeceği gerçeğinden hareketle, insanlara küçük yaşlarda konuşma eğitimleri verilmelidir. Ülkemizde MEB’in çocuklara kazandırmak istediği beceri de bu yöndedir: “Anlaşmanın en yaygın ve doğal biçimi konuşmadır. Bunun içindir ki çocuklarımıza her şeyden önce doğru ve düzgün konuşmak, anlatmak istediklerini en kısa yoldan, en açık ve karşıdakilerin zihinlerinde karanlık bir nokta bırakmayacak biçimde anlatma beceri ve alışkanlığımı kazandırmak gerekir” (MEB, 2002: 8). Bu hedefin gerçekleştirilmesine dönük öğretim programları oluşturulmalıdır.

\section{Dilsel verinin çözümlenmesinde dinleyicinin özellik, görev ve sorumlulukları}

Konuşma ve dinlemenin oluşturduğu iletişimsel bir etkinlikte dinleyicinin önemli görev ve sorumlulukları vardır. "Her ne kadar gönderen (konuşan), alıcıdan (dinleyen) daha etken ise de bundan konuşma eyleminde alıcının edilgen bir rol oynadığı sonucunu çıkarmak yanlıştır” (Taşer, 2000: 207). Her iletişimde sistematik, özetleyici ve ana fikri vurgulayan; anlamayı kolaylaştırmak için birçok strateji kullanan konuşmacılar bulunmaz. Bu nedenle konuşma içinden gerekli veriyi çekip çıkarma görevi dinleyicidedir. İletişimde dinleyicinin, konuşmayı dilsel yönden anlamlı kılacak özelliklere sahip olması gerekir.

İnsanın iç konuşması dilseldir ve dinlemeye etki eder. Kişinin kelimelere yüklediği anlamlar, gramer bilgisi, mecazlara aşinalığı, imalı ve esprili anlatımlardan hoşlanması, düşünceleri, zihniyeti, ön bilgileri (insanlardan, olaylardan, kitaplardan, filmlerden, müzik yapıtlarından, görsellerden zihninde kalmış imajlar, pasajlar, cümleler, sözcük grupları, kelimeler, söz oyunları, metaforlar vb.) dinleme sırasında açığa çıkar. "Dinleyici; sahip olduğu algılar, tutumlar, değerler, geçmiş deneyimler, kelime hazinesi, eğitim seviyesi ve kültüre göre mesaja anlam vermektedir” (Kushal, 2009: 96). Bu durum, konuşmacının bilemeyeceği, dışarıya fazla yansımayan bir özelliktir.

Kafa sesi ya da zihin dili denilen iç ses; dışarıdaki konuşmalara firsat vermeden zihni; sözcük, cümle ve görüntülerle etkisi altına alır. Aynı zamanda iç iletişimin yargılayıcı, buyurgan ve alaycı dili kendini gösterir. Adeta beyinde bir sis bulutu oluşturan düşüncelerin arasından dinleyici, konuşanın söylediklerinin üstünde tüten anlamı seçmek ve anlamak için kendini zorlar. Karşıdakini dinlerken kendini de dinleyen dinleyici, anlama ulaşmak için bu ses duvarlarını aşmak zorundadır. Dinleyicinin böyle durumlarda kendisini değil de konuşmacıyı merkeze alması halinde dinleme eylemi daha verimli olur. Bu bakımdan dinleyici, anne karnındaki bir bebek gibi, dışarıdaki hayatla olan bağını öncelikli hale getirmeli, zihnini içe değil, dışa odaklamalıdır.

Konuşan kişiler, genellikle, dinleyicilerinin onları kolayca anladıklarını zannederler oysa anlaşılma, dinleyicinin birçok olumsuzluğu bertaraf ederek konuşmaciyla bütünleşmesiyle mümkündür. Rahat olmak, dikkat, odaklanma, sabır, olumlu tutum, sözün sonunu bekleme, tarafsızlık, empati, ön yargıdan uzak olmak, sözlü ve sözsüz onay tepkileri vermek, konuşmacıya dönük olma ve rahatsız etmeyen göz teması... Daha pek çok özellik dinleme sırasında etkili bir şekilde yönetilmelidir.

Dinleyicinin bakış açısı, dinleme etkinliğinin niteliğini belirler. Konuşmanın ne kadar ve nasıl anlaşılacağı, tutum ve bakış açlarına göre değişir. Bu tür insani özellikler, en az dilsel özellikler kadar dinleme performansını etkiler.

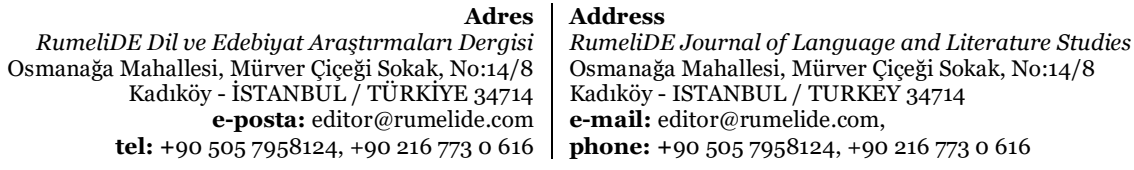


Etkili bir dinleyici, konuşmacının sözcük seçimini incelemeye alır. Verdiği örneğin tutarlılığını, yaptığı konuşmanın kompozisyonunu irdeler, konuşmadaki gerekliyi gereksizi, ilişkili ve ilişkisiz olanı ayırt eder. Adeta konuşmanın röntgenini çeker. Ayrıntıyı ve içeriği netleştirir ancak bunlara takılmadan, öncelikle mesajın ve mesajla birlikte yansıtılan duygu ve amacın ne olduğunu anlamaya çalışır.

Dinleyicinin olgunluğu önemli bir husustur. Konuşanın sunduğu veriyi açacak oranda yeterli tecrübe ve bilgiye sahip olmayan, bu olgunluğa ulaşamamış bir dinleyici; alıcı olma görevini tam olarak yerine getiremez. Mecazlı, kinayeli, ironik, nükteli, imalı, esprili vb. sözlerin anlaşılamaması, bu noktada dinleyicinin hem olgunluğu hem de yeterli bilgi birikimine sahip olmamasıyla ilişkilidir. Dilin yüzeyinde kalıp, asıl anlatılmak istenen noktaları gözden kaçıran, söylenenlerin bir kulağından girip diğer kulağından çıtığı bir dinleyicinin, iletişimde bulunduğu söylenemez.

Bir dinleyicinin, karşısındakinin duygu ve düşüncelerini anlayı çözmesi sadece eğitim durumuyla açılklanamaz. Herhangi bir eğitim almamış bazı insanların etkili dinleyiciler oldukları; dilsel verileri, iletişim alanının profesyonellerine göre daha iyi açıp çözümleyebildikleri görülür. İşin içine karakter özellikleri, yaş, deneyim, etkili dinleyici olma, tutumlar vb. girer. Bu noktada yetişkinlerin gençlere göre avantajlı olduğu bilinmelidir. Yetişkinlerin zamanla dile olan hâkimiyetleri arttığı için anlama ve anlaşmaları daha kolay olur. Gençler, sözcüklerin kullanımı ve bağlam noktasındaki deneyim eksiklerinden dolayı mesajları derinlikli bir şekilde anlamayabilirler. Bu nedenle "Dinlemenin sadece zamanla ve yaşantılar yoluyla geliştirilebilecek becerileri kapsayan bir sanat olduğunu bilmeliyiz" (Şahinel, 2002: 12). Dinleme, diğer beceriler gibi, zamanla gelişen ve iyileşen bir beceridir.

Dilsel verinin, duyguları olumlu veya olumsuz harekete geçirmesine izin vermeden anlamak önemlidir. Ancak bu, robotik bir çözümleme demek değildir. Sözcükler bazen dile getirdiklerini gizler, farklı şeyler anlatır. Bu bakımdan dinleyicinin, sözcüklerin üstündeki vurgu, ton, durak, ezgi, ünlem gibi özellikleri dikkate alması, bunları da dilsel kodlar gibi çözümlemesi gerekir. Bilinçaltı, ana dilde, bu işlemleri kendiliğinden yapar. Ancak bilinçli olmak da gerekir. Özellikle söylemde gizli, manipülatif şeyler bulunabilir. İyi bir dinleyici olmak, bu bakımdan, kulağını iyice açmayı, leb demeden leblebiyi anlayacak şekilde dikkatli ve uyanık olmayı gerektirir.

Dinleyici, aslında, konuşmacının bir adım önündedir; tıpkı metinde (konuşma kompozisyonunda) bir sonraki bölümde neler geleceğini/olacağını tahmin eden bir okur gibi. Bir anlamda dinleyicinin; konuşmacının aklını okuması, aklından geçenleri çözümlemesi, tahminlerle bunları anlamaya çalışması söz konusudur.

Dinlerken gösterilen nezaket, dilsel veriyi algılamada önemli bir etkendir ve dille ortaya konulan bilgi, duygu ve düşüncelerin doğru anlaşılmasına zemin hazırlar. Bir insanın dinlemeye hazır olması birçok şeyi değiştirir. Karşıdakinin sözcükleri, cümleleri, ünlemleri, vurguları anlam kazanır.

Her insanın kullandığı farklı filtreler vardır. Bazı insanlar, her türlü verinin kolayca geçtiği esnek ve geniş filtreler kullanırken bazıları çeşitli faktörler (zaman darlığı, ön yargı, dile olan hâkimiyet, ilgisizlik, seçici olma vb.) nedeniyle filtrelerini oldukça hassas yapılandırırlar ve o filtreden verilerin geçmesi kolay olmaz.

Dil zevkine, dil bilincine ulaşmış bir insan, dinlediklerinden önemli oranda zevk alır. Kitap okumanın insanı tatmin etmesi gibi, nitelikli bir konuşmayı dinlemekten benzer hazzı duyar. Dinledikleri içinde

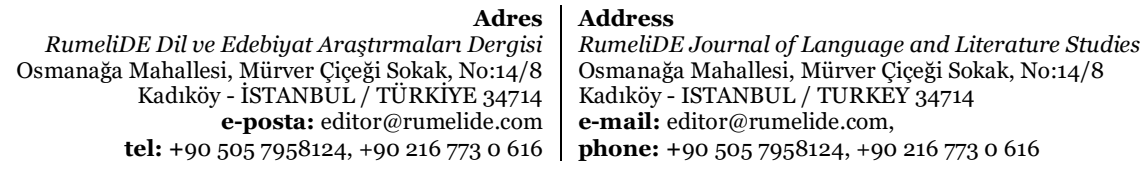


geçen önemli şeyleri, güzel cümleleri, alıntıları zihninin not defterine ekler. Bu, bazen anlık bazen gecikmeli bir şekilde gerçekleşir.

Tartışmalarda dinleyiciler, dilsel verilerin hem altını hem üstünü çizer ve kurulan cümleler flulaşır. Sözcüklerle birlikte akan ve onlardan daha fazla anlam ifade eden şey; duygular, tutumlar, ön yargılar ve bakış açıları olur.

Bir konuşmayı dinlerken önemli olan, ana fikri ve temel iletiyi yakalamaktır. Dilsel ifadelere gizlenmiş örtük anlamları, bağlam içerisinde netleşen sözcükleri doğru ve uygun şekilde anlamak gerekir. Konuşanın yaptığı birleştirmeler dinleyici tarafından çözümlenip değerlendirilir. Bu bakımdan konuşma sentez, dinleme analizdir.

Dinlemede biliş kadar üst biliş de önemlidir. Dinleyen kişi, anlayıp anlamadığını sorgulamalıdır. Konuşanın kendi söylediklerini dışarıdan duymasının güç olması gibi, dinleyicinin de nasıl dinlediğini tam olarak bilebilmesi mümkün değildir. Konuşmacı konuştuğunu, ne söylediğini unutmasa da; dinleyici dinlediğini, nasıl dinlediğini unutabilir. Dinlemede biliş ve üst biliş aynı anda aktif olmazsa dilsel veriler tam olarak çözülemeyeceği gibi, dinleyen kendi iç konuşmalarının dinlemesini ne oranda etkilediğini de bilemez. Bu bakımdan üst bilişsel bir dinleme, aynı zamanda, stratejiktir. Dinleyici ne dinlediğini, ne anladığını ve dinleyip anladıklarını ne yapacağını ölçüp tartar.

Konuşmacı, iletileri düzenlemede zorlanıyorsa ona yardımcı olmak üzere dinleyicinin dönüt vermesi, yerinde bedensel tepkilerde bulunması, anlattıklarını açarak genişletmesi ve samimi, iyi niyetli yaklaşması uygun olacaktır. Böyle bir durumda konuşmacı, dinleyiciye gereken dilsel veriyi daha net ve etkili bir şekilde sunabilir. "İyi bir dinleyici sadece söze ve kelimelerin ardındaki anlama bütünüyle ilgi gösteren kişi olmakla kalmaz, aynı zamanda da konuşan kişiyi düşünce ve duygularında bir genişleme sağlamasına neden olacak şekilde teşvik eder" (Shafir, 2003: 33). Dinleyicinin bu hassasiyeti, konuşmacının kelimelerini değiştirebilir.

Dinleyici, bir konuşmada tekrar, tahmin, tanım ve tanık arayacaktır. Uygun tanımların olduğu, ana fikir ve yan fikirlerin yeri geldiğinde tekrarlandığı, akışın tahmin edebileceği ve tanık gösterilerek zenginleştirilmiş bir konuşma, dinleyicinin üst düzey verim almasını sağlar.

Olağanüstü durumlarda (felaketler, duygusal anlar, krizler, savunma anları vb.) dinleyicinin dikkati üst düzeydir. Böyle anlarda her bir dilsel veri, bilinç ve bilinçaltında kalıcı etkiler bırakır. Günlük paylaşım ve diyaloglarda ise birçok veri kaybı yaşanır ve sözcükler hedefi bulmaz. Kulak vermeden ses almayı beklemek boş bir çaba olur. Dinleyicinin bazı tepkileri bunun göstergesidir. Boş ver, olur öyle şeyler, hayırlısı, aynen, katılıyorum vb. Türkçedeki bazı kalıp ifadeler, aslında dinleyicinin konuşmacıyı dikkatle dinlemediğini gösterir.

Dinleyici, sinyal ve değişimleri fark eden bir çözücü (dekoder) gibi, sesteki en küçük titreme, çatlama, bozulma ve düzelmeleri çözümler.

Konuşmacının ne kadar çok sözcük bildiğinden öte, kendini ne kadar iyi ifade edebildiği önemlidir. Aynı şey dinleyici için de geçerlidir. Dinleyicinin söz varlığı çok gelişmiş olsa da, dinleme sırasında neyi ne kadar anladığı önemlidir. Bu nedenle "Anlam, sözcüklerden ziyade insanlardadır" (Altıntaş ve Çamur, 2014, s. 16). Hem konuşmacı hem de dinleyici, ne anlattığına ve ne anladığına odaklanmalıdır.

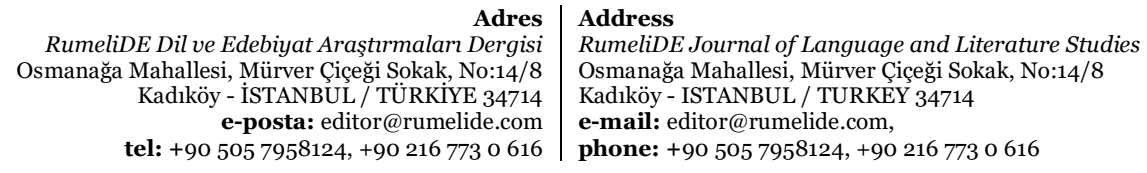


Düşündüğünü söyleme görevi ve sorumluluğu konuşmacıdayken söyleneni düşünme sorumluluğu dinleyicidedir. "Söyleyenden dinleyen arif gerek." derler. Öyle konular olur ki anlatan, kapalı konuşur. O zaman dinleyen, söyleyenin ne demek istediğini anlamak zorunda kalır. "Söz dediğin yaş deridir, nereye çekersen oraya gider.” misali sözler çeşitli anlamlara gelebilir. Dinleyen, konuşanın asıl söylemek istediğini anlamaya çalışmalıdır.

\section{Dinlemenin dilsel yönüyle eğitimi}

Dinlemenin, Türkiye'de özellikle son yıllarda öğretim programlarında yer aldığı, eğitimlerinin yapıldığ bilinmektedir. Ancak bu eğitimlerin, dinlemenin zihni besleyen bir araç olma özelliğine atıf yaptığı ve dil becerisi olduğu vurgusuna rağmen, tam olarak dilsel yönüne dönük olmadı̆̆g dikkati çeker.

Dinleme becerisinin dilsel yönüne yatırım yapılmalı, bu yeterliği geliştiren eğitimler verilmelidir. Nasıl ki eğitim öğretim kurumları bireylerde, daha çok, okuma alışkanlığını geliştirmeyi hedefliyorsa benzer şekilde, bir anlama faaliyeti olan etkili dinleme alışkanlıklarını da geliştirmeli ve bunu bir amaç edinmelidir. Okumaya yapılan yatırımın dinlemeye yapılmaması, dinlemenin anlaşılmamasından ve dilsel yönünün bilinmemesinden kaynaklanır.

Dile ait kodların uygun şekilde çözümlenmesi dilsel yeterliğin gelişmesi ile doğru orantılıdır. Çocuğun henüz okulla tanışmadığı okul öncesi dönemden, ev hayatından başlanacak olursa çok küȩük yaşlardan itibaren dilsel verileri çözümlemeye dönük eğitimler olmalıdır. Erken yaşlarda başlayan dinleme eğitimi, öğrenme sorunları olan çocuklara da önemli faydalar sağlar. "Çoğu öğrenme uzmanı, öğrenme güçlüğü yaşayan birçok çocuğun evde yeterli derecede iyi dinleme örneğiyle karşılaşmamış oldukları fikrinde birleşmektedirler” (Shafir, 2003: 30). Örneğin, masal okunan çocuklar, söz konusu masallardaki içeriği dilsel veriden anlamak zorundadır. Evdeki bireylerin iletişim kurarken birbirlerini nasıl dinledikleri çocuğun dikkatini çekecektir. Dil taklitle öğrenilip taklitle geliştiriliyorsa etkili dinlemelere maruz kalmak gerekir. Çocuğun, aile bireylerini model alarak gerçekleştireceği öğrenmeler, hayatı boyunca nasıl bir dinleyici olacağına etki edecektir.

Formal eğitimde dinlemenin bir dil becerisi olarak alt yapısını oluşturmak ve bu beceriyi geliştirmek için ilkokuldan başlanarak dinleme ve izleme çalışmaları yaptırılır. Bu çalışmalarda metinler okunur, masal dinlenir, fabl izletilir; belgeseller, filmler incelemeye alınır; gerçek yaşam durumlarına benzer olaylar ve kurgular üzerinde çalışma ve etkinlikler yapılır.

Tüm becerilerin temelini oluşturmasına rağmen dinleme eğitimi ciddi ve bilimsel bir şekilde yapılmaz. Dinleme de konuşma gibi, çocuk daha okula gelmeden öğrenilmiştir. Ancak bu, planlı ve programlı bir eğitiminin yapılmayacağı anlamına gelmez. Çocuklara etkili ve hızlı dinleyip anlama kavratılmalıdır.

Dinlemenin dilsel yönü kendi kendine gelişmez, bunun için sistematik eğitimlere ihtiyaç vardır. "Dinleme çalışmalarında kendi kendini kontrol edebilme becerisi çok önemlidir. Çünkü öğrenciler başarılı bir dinleme gerçekleştirip gerçekleştirmediklerini ya da kullandıkları dinleme stratejilerinin işe yarayıp yaramadığını fark edebilmelidir” (Özbay, 2010: 130). Özellikle de küçük yaşlardan itibaren dinlemeye ilişkin bir farkındalık kazandırılmalıdır.

Dinlemenin dilsel yönü, dilsel gelişim sağlar. Kültürlü, çok okumuş, bilgili, hayat deneyimleri olan, sözcükleri seçerek konuşan, zihinsel yetenekleri gelişmiş, iletişime ve dile değer veren, esprili vb. özellikteki kişileri dinlemek; onlardan birçok şeyi öğrenmeyi, kişinin kullandığı dili zenginleştirmesini

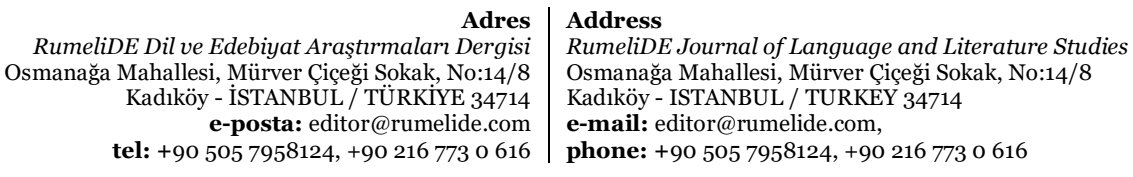


beraberinde getirir. Bu sayede sözlüğe bakmadan sözcükleri bağlam içinde anlamak, sözcük nüanslarını fark etmek, dilin önemini kavramak mümkün olur.

Dinlemenin bir aşamasının tepki olması nedeniyle dinlemedeki dilsel verinin ne kadar anlaşıldığı konuşmayla açığa çıkar. Kişiye ne dinlediğini, neyi ne kadar anladığını ifade etmesi için sorular sorulmalı, ondan dönütler istenmelidir. Benzer şekilde, dinlemenin niteliği yazılı çalışmalarla da açığa çıarılır.

Dilsel eğitim, bireylerin dinleme becerisini geliştirmenin bir parçasıdır. Bunun dışında bireyin dinleme nezaketinden empatiye, dikkatten ön yargısız değerlendirmeye kadar dinleme becerisinin parçalarını oluşturan birçok noktada yetişmiş ve eğitilmiş olması gerekir. Ancak bu sayılanlar, dilsel olmaktan çok iletişimsel bir eğitim almayı zorunlu kllar.

Okullarda dinlemenin dilsel yönden eğitimine dönük aşağıda sıralanan etkinlik ve çalışmalar yapılabilir:

- $\quad$ Estetik yönü güçlü, öğrenci seviyesine uygun, nitelikli bir dille oluşturulmuş, seçkin edebî ürünler okunmalı ve çözümlenmelidir. Bu tür bir çalışmada, söz konusu metinleri öğretmenin okuması daha uygun olacaktır. Sesletilen metinler, dinleme öncesi veya sonrasında verilen açık ve kapalı uçlu sorularla çözümlenir. Metindeki sözcükler, sözcük grupları, deyimler, varsa atasözleri ve özlü sözler belirlenir; dilsel içerik çeşitli açılardan (sözcük türleri, aynı kavram alanından sözcüklerin kullanımı, sözcüklerin tekrarı, bağlam içindeki yeri, günlük hayattaki kullanımı, bilinip bilinmeme durumu, kültürle ilişkisi, yabancı olup olmadıkları vb.) incelenip değerlendirilir.

- $\quad$ Sadece seçkin metinler değil, seçkin şarkılar, filmler, kısa filmler, belgeseller, ses kayıtları vb. dinletilip izletilir. Bu metinlerdeki anlam, neden sonuç ilişkileri, öznel-nesnel ifadeler ortaya konulur; yorum ve çağrışımlarla, metinlerarası ilişkilerle metin dışına çıkarak analiz ve değerlendirmeler yapılır. Ayrıca duygusal ve düşünceye dayalı açıklamalar, çelişkiler, tutarlılık, bilimsellik gibi özellikler belirlenir.

- Metinler üzerinde üslup çalışmaları yapılır. Üslup çalışmaları da dilseldir ve yazarın dili nasıl kullandığını yansıtır. Öğrenciler, dinledikleri metinlerde yazarın dili kullanma (süslü, sade dil kullanımı), betimlemeleri kullanma biçimini; abartıya başvurup başvurmadığını, döneminin algı ve kültürünü yansıtıp yansıtmadığını, cümle oluşturma tarzını, iyimser-karamsar dil kullanımını, esere müdahalelerini, ciddi veya samimi dil seçimini, konu dışına çıkıp çıkmadığını vb. incelemeye alır.

- $\quad$ Öğretmenin seslettiği veya sesletilmiş dijital metinler öğrencilere sunulur ve bu metinlerde yazarın kullanmış olduğu stratejiler ve düşünceyi geliştirme yolları belirlenir. Bu stratejilerin uygunluğu ve düşünceyi geliştirme yollarının metne katkıları ele alınır. Benzetme, tanımlama, örnekleme, tanık gösterme, konuşturma, yineleme, sinfflandırma, karşıtlama, halk söyleminden yararlanma, argodan yararlanma, betimleme, özetleme gibi strateji ve düşünceyi geliştirme yolları aranır ve bunların yerinde kullanılıp kullanılmadığı sorgulanır.

- Metinler, ses değeri ve dil ötesi ögeler bağlamında analiz edilir. Sesletim sırasında vurgulanan ifadeler, tonun değiştiği sözcükler, ritmin ve durakların kattığı değer vs. incelenir.

- $\quad$ Bir öğretmen, ortama gelen/dijital araçlarla bağlanan bir konuşmacı veya bir öğrenci; belirli bir konuda konuşma yapar. Bu konuşmalar, sözlere nasıl başlandığı, sözlerin nasıl bitirildiği, konuşmanın dikkate değer noktaları vb. yönleriyle incelenir.

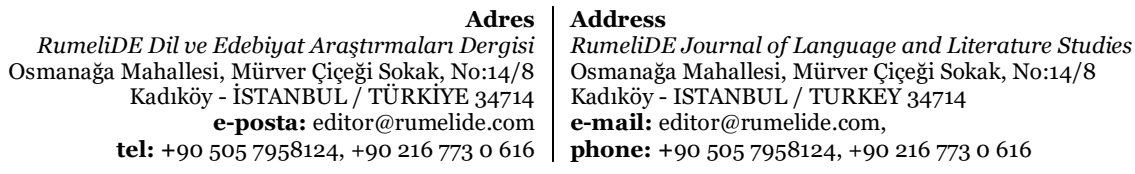


- $\quad$ Dinletilen metinler özetlenir (sözlü veya yazılı olarak), metinlerin başlı̆̆ı ve anahtar kelimeleri tespit edilir.

- $\quad$ Konuşmanın kompozisyonunu fark etmeye dönük bir dinleme yaptırılır. Metinlerin küçük ve büyük ölçekli yapılar itibarılla bütünlüğü sorgulanır. Duygu ve düşüncelerin uygun ahenk ve düzen içinde konuşmaya yansıtılıp yansıtılmadığına bakılır.

- $\quad$ Anlatım bozukluğu olan, zaman uyuşmazlığı bulunan, kelime seçimlerinin cümledeki yere göre hatalı olduğu vb. sorunlu dilsel yapılar dinletilerek öğrencilerden bu metinlerde yer alan hataları bulmaları ve bunların doğrularını ifade etmeleri istenir.

- Televizyon kanallarındaki spiker, program sunucuları ve katılımcıların dilsel hatalarına dönük ev ödevleri verilir.

- Soru işaretleriyle dinlemek; dinlemeyi etkili ve anlamlı kılar. Türkçedeki ne, niçin, nerede, nasıl, ne zaman, kim, kaç, hangi, mi vb. soru ek ve kelimeleri; dinlemede dilsel içeriğin çözümlenmesine, anlaşılır hale gelmesine katkı sağlar. Bu doğrultuda etkinlikler yapılır.

- Bağlamından koparılmış cümleler üzerinde çalışmalar yapılır.

- Yarım bırakılmış konuşmalar tamamlanır.

- Yarım bırakılan atasözleri tamamlanır.

- Boşluk doldurma çalışmaları yapılır. Öğrencilere, içeriğindeki bazı kelime ve kelime gruplarının çıarıldı̆̆ı şiirler, şarkı sözleri, düşünceye veya olaya dayalı metinler dinletilir. Öğrencilerden, bu boşluklara gelecek ifadeleri belirlemeleri ve dinleme sonrasında bunları arkadaşlarıyla paylaşmaları istenir.

- Kişinin dinleme yeterliğini anlamanın bir başka yolu da dikte çalışması yaptırmaktır. "Dikte çalışmalarında kişi duyduğunu yazdığından bu seslerin kulakla öğretilmesi amaçlanmaktadır. Kelime ve seslerin yanlış şekillerini dinleme yoluyla öğrendiklerinden bunların düzeltilmesi de dinleme ile giderilmelidir” (Erdem, 2014: 215). Dikte çalışmalarının dinlemeye önemli katkıları olacaktır.

\section{Sonuç ve öneriler}

Dinlemenin iletişimsel ve dilsel yönü iç içedir. Bu çalışmada, dinlemenin dilsel yönü ön plana çıkarılmış ve bu amaçla dinleme faaliyetine dilsel yönden etki eden nedenler belirlenmiştir. Çıkan sonuç; dinlemeyi öncelikle bir dil becerisi olarak ele almak, dinlemenin dilsel verilerle bağlantısını ortaya koymak, dinleme becerisinin dilsel yönünü geliştirmek için dile ve söyleme ilişkin bir bakış açısı geliştirmek, dinlemeyi hem günlük hem resmî hem de akademik ortamlarda diğer dil becerileriyle bütünleşik bir şekilde değerlendirmek, dil yetisini geliştirmeye dönük etkinlik ve çalışmalarda bulunmak, Türkçenin dil, dil bilgisi ve konuşma özelliklerini bilmek, etkili bir dinleyici olmak için çaba göstermek gerektiğidir.

Dinleme üzerinde etkide bulunan konuşmacının, hem konuşmacı hem de dinleyici olduğunu gözeterek, söylediklerinin en açlk ve anlaşılır bir şekilde dinleyiciye ulaşması için gerekli duyarlılık ve yeterliği göstermesi gerekir. Çünkü konuşmacı, dinleyici üzerinde etki sahibidir. Bu noktada, bazı yayınlar

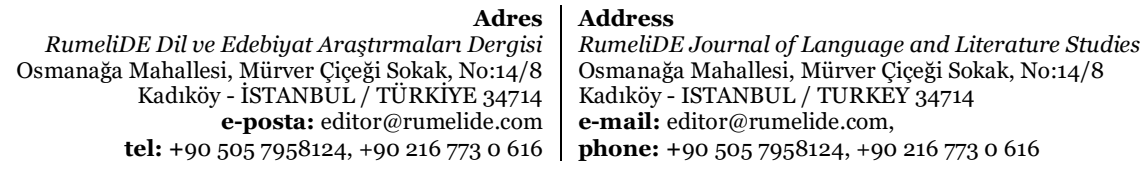


(Aşılıoğlu, 2009; Emiroğlu, 2013; Dinçel, 2018; Başkan ve Deniz, 2015), konuşmacının çeşitli nitelik ve davranışlarının dinleme ve dinleyici üzerinde etkili olduğunu ortaya koymuştur.

Çalışmada, dilsel verinin dinleme üzerindeki etkileri belirtilmiştir. Vurgulanan düşünceler, dinlemede ses bilgisel ve prozodik farkındalı̆̆ın önemine dikkat çeken yayın ve araştırmalarda (Crandell, Smaldino ve Flexer, 2005; Özbay ve Çetin, 2011) da dile getirilmiştir.

Çalışmada, dinlemenin dilsel yönüyle eğitimi başlığı altında birçok etkinlik ve çalışmaya yer verilmiştir. Dinleme eğitimiyle ilgili bazı yayınlarda (Doğan, 2010; Mert, 2014) da dinlemenin dil odaklı eğitimiyle ilgili etkinlikler yer almıştır.

Çalışma sonucunda ortaya çıan öneriler ise şu şekilde sıralanabilir:

- $\quad$ Dinleme ve konuşmanın birlikteliği düşünülerek çok küçük yaşlardan itibaren her iki beceriyi dilsel yönden geliştirecek çalışmalar yapılmalıdır.

- Yetişkinlerin, anlama ve anlatmayı "anlaşılırlık" çatısı altında birleştirmesi ve buna uygun dinleyici ve konuşmacı olmaya gayret etmesi gerekir.

- Dinlemenin dilsel yönü, bu çalışmada olduğu gibi, ayrıştırılıp incelenebilir. Ancak dinlemenin dilsel yönünün iletişimsel yönünden koparılamayacağı bilinmeli, çalışmalarda iletişim ortamları dikkate alınmalıdır.

- $\quad$ Dinleme eğitimiyle ilgili yayınların, dinlemenin iletişimle ilişkisine değinmek kadar, dilsel yönüne de vurgu yapması ve bu noktada daha fazla bilgi vermesi gerekir.

- $\quad$ Ana dili ve yabancı dil eğitimlerinde dinleme becerisinin kazandırılmasında, dinlemenin dilsel yönüne ilişkin, uygulamaya dayalı çalışmalar yapılmalıdır.

- $\quad$ Anlama başlığı altında birleşen dinleme ve okuma, dilsel yönden birbirine benzer. Okuma eğitimine yapılan yatırım dinlemeye de yapılmalıdır. Dinlemeyi, hızlı dinleyip anlamayı, dil odaklı dinlemeyi geliştirmeye odaklı kurslar açılmalıdır. Bu tür proje ve çalışmalarla dinlemenin önemi artırılmalıdır.

- $\quad$ Dinleme ve izleme yan yana ve birlikte ele alınsa da, dinlemeyi artırmak için izlemeyi kesmek gerekebilir. Görselliğin her şeyi kuşattığı bir dünyada sese verilen değeri artırmak bakımından dinlemenin tekrar gözden geçirilmesi gerekir.

\section{Kaynakça}

Aktaş, Ş. ve Gündüz, O. (2004). Yazılı ve sözlü anlatım kompozisyon sanatı (5. Baskı). Ankara: Akçağ.

Altıntaş, E. ve Çamur, D. (2005). Beden dili, sözsüz iletişim. (3. Baskı). İstanbul: Aktüel Yayınları Alfa Akademi.

Arslanoğlu, İ. ve Duman, E. Z. (2018). İnsan ilişkileri ve iletişim. Ankara: Nobel.

Aşılıoğlu, B. (2009). Türkçe öğretmen adaylarına göre derslerde karşılaşılan başlıca dinleme engelleri. Elektronik Sosyal Bilimler Dergisi, 8(29), 45-63.

Aytan, T. (2011). Aktif öğrenme tekniklerinin dinleme becerisi üzerindeki etkileri (Yayınlanmamış Doktora Tezi). Selçuk Üniversitesi Eğitim Bilimleri Enstitüsü, Konya.

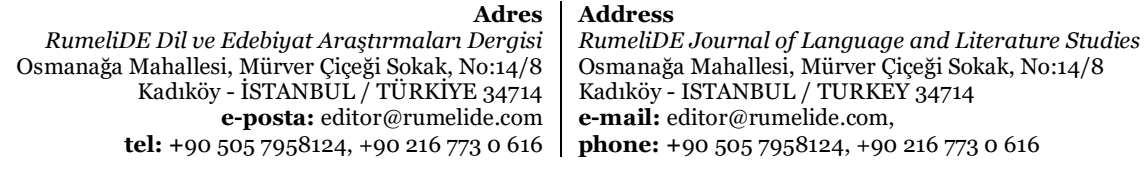


Baltaş, Z. ve Baltaş A. (2001). Bedenin dili. (29. Basım). İstanbul: Remzi.

Başkan, A. ve Deniz, E. (2015). Ortaöğretim öğrencilerinin ders içi dinleme sorunları (Malatya ili örneği). Turkish Studies, 10(7), 179-196.

Brysbaert, M. et al. (2016). How many words do we know? practical estimates of vocabulary size dependent on word definition, the degree of language input and the participant's age. Frontiers in Psychology.

Crandell, C. C., Smaldino, J. J. ve Flexer, C. (2004). Sound field amplification: Applications to speech perception and classroom acoustics. San Diego, CA: Singular.

Çakır, A. (2014). Söylem analizi ne demek istiyorsun? Konya: Palet.

Çankaya, Z. C. (2004). Kişilerarası iletişimde dinleme becerisi. Ankara: Nobel.

Çongur, R. (1999). Güzel söz söyleme. Ankara: TRT.

Demirel, Ö. ve Şahinel, M. (2006). Türkçe öğretimi. Ankara: PegemA.

Dinçel, B. K. (2018a). Ortaokul öğrencilerinin Türkçe dersinde yaşadıkları dinleme sorunları ve sorunların çözümüne yönelik beklentileri. Uluslararası Türkçe Edebiyat Kültür Eğitim (TEKE) Dergisi, 7(4), 2551-2571.

Dinçel, B. K. (2018b). Dinleme eğitimi üzerine araştırmalar. A. Akçay (Ed.). Dinleme/izleme eğitimi içinde (s. 205-244). Ankara: Nobel.

Doğan, Y. (2010). Dinleme becerisini geliştirmede etkinliklerden yararlanma. Türklük Bilimi Araştırmaları. (27), 263-274.

Eker, S. (2004). Çağdaş Türk dili. Ankara: Grafiker.

Emiroğlu, S. (2013). Türkçe öğretmeni adaylarının dinleme sorunlarına ilişkin görüşleri. Adıyaman Üniversitesi Sosyal Bilimler Enstitüsü Dergisi, (11), 269-307.

Erdem, İ. (2014). Konuşma eğitimi: kuram, uygulama, ölçme ve değerlendirme. A. Güzel ve H. Karatay (Ed.). Türkçe öğretimi el kitabı içinde (s. 181-220). Ankara: Pegem.

Güneş, F. (2016). Türkçe öğretimi yaklaşımlar ve modeller. (4. Baskı). Ankara: Pegem Akademi.

Gürüz, D. ve Eğinli, A. T. (2010). Temel iletişim becerileri anlamak-anlatmak-anlaşmak. Ankara: Nobel.

Işık, M. (2013). Genel ve teknik iletişim. Konya: Eğitim.

İmer, K., Kocaman, A. ve Özsoy, A. S. (2011). Dilbilim sözlüğü. İstanbul: Boğaziçi Üniversitesi.

İşeri, K. (2008). Dinleme eğitimi. A. Tazebay ve S. Çelenk (Ed.). Türkçe öğretimi ilke yöntem teknikler içinde. (s.160-185). Ankara: Maya Akademi.

Kardaş, M. N. (2018). Dinleme eğitiminde not tutma. A. Akçay (Ed.). Dinleme/izleme eğitimi içinde (s. 147-184). Ankara: Nobel.

Kıymaz, M. S. (2018). Dinlemeyi etkileyen unsurlar. A. Akçay (Ed.). Dinleme/izleme eğitimi içinde (s. 119-146). Ankara: Nobel.

Kaya, A. (2014). İletişime giriş: temel kavramlar ve süreçleri. A. Kaya (Ed.). İnsan ilişkileri ve iletişim içinde. (s. 1-29). Ankara: PegemAkademi.

Kayaalp, İ. (1998). İletişim ve dil. İstanbul: Türkiye Diyanet Vakfi.

Kurudayığlu, M. ve Kiraz, B. (2020). Dinleme stratejileri. Ana Dili Eğitimi Dergisi, 8(2), 386-409.

Kushal, S. J. (2009). Business communication. India: VK Enterprises.

Mackay, I. (1997), Dinleme becerisi. (A. Bora ve O. Cançolak, Çev.), Ankara: İlkkaynak Kültür ve Sanat Ürünleri.

Maviş, A. (2006). Söz söyleme ve insanları etkileme sanatı. İstanbul: Hayat.

MEB. (2002). İlköğretim okulu Türkçe-yazı programı 6-7-8. sınıf. İstanbul: Milli Eğitim.

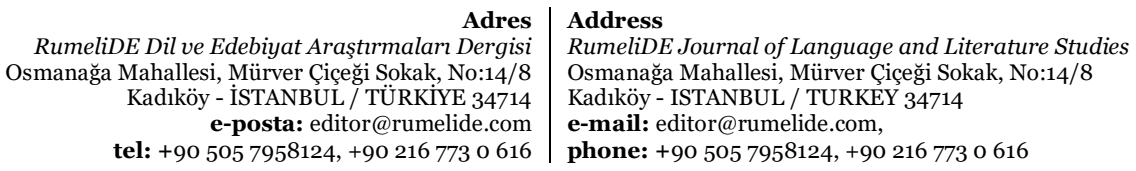


Mert, E. (2014). Türkçenin eğitimi ve öğretiminde dört temel dil becerisinin geliştirilmesi sürecinde kullanılabilecek etkinlik örnekleri. Ana Dili Eğitimi Dergisi, 2(1), 23-48.

Meyer, M. (2009). Retorik. (İ. Yerguz, Çev.). Ankara: Dost.

Özbay, M. (2009). Anlama teknikleri II: dinleme eğitimi. Ankara: Öncü Kitap.

Özbay, M. ve Çetin, D. (2011). Dinleme becerisinin geliştirilmesinde prozodik farkındalığın önemi. Muğla Üniversitesi Sosyal Bilimler Enstitüsü Dergisi, (26), 155-175.

Peterson, R. D., Karschnik, Jr. Kevin J. (2011), Coaching communication, Austin: İspeak Prentice-Hall Inc.

Porzig, W. (1985). Dil denen mucize I. (V. Ülkü, Çev.). Ankara: Kültür Bakanlığı.

Shafir, R. (2003). Dinlemenin zen’i. (I. Uçkun, Çev.). İstanbul: Ruh ve Madde.

Soyer, T. (2016). Araştırmalarda kaynak kullanımı, ölçme ve değerlendirme, akademik yükselme ve atanma ölçütleri. Çocuk Cerrahisi Dergisi, 30(1), 21-26.

Şahinel, S. (2007). Eleştirel düşünme. (2. Baskı). Ankara: PegemA.

Taşer S. (2009). Konuşma eğitimi. İstanbul: Pegasus.

Temur, T. (2010). Dinleme metinlerinden önce ve sonra sorulan soruların üniversite öğrencilerinin dinlediğini anlama beceri düzeyine etkisi. Selçuk Üniversitesi Ahmet Keleşoğlu Eğitim Fakültesi Dergisi, 29, 303-319.

Temizyürek, F., Erdem, İ. ve Temizkan, M. (2011). Konuşma eğitimi: sözlü anlatım. Ankara: Öncü Kitap.

Tompkins, G. E. (1998). Language arts content and teaching strategies. New Jersey: California State University, Prentice-Hall Inc.

Umagan, S. (2007). Dinleme eğitimi. A. Kırkkıllı̧ ve H. Akyol (Ed.). İlköğretimde Türkçe öğretimi içinde. (s. 149-163). Ankara: PegemA.

Vardar, B. (2002). Açıklamalı dil bilim terimleri sözlüğü. (2. Baskı). İstanbul: Multilingual.

RumeliDE Dil ve Edebiyat Araştırmaları Dergisi Osmanağa Mahallesi, Mürver Çiçeği Sokak, No:14/8 Kadıköy - İSTANBUL / TÜRKIYE 34714 e-posta: editor@rumelide.com tel: +90 $5057958124,+902167730616$
Address

RumeliDE Journal of Language and Literature Studies Osmanağa Mahallesi, Mürver Çiçeği Sokak, No:14/8

Kadıköy - ISTANBUL / TURKEY 34714

e-mail: editor@rumelide.com,

phone: +90 $5057958124,+902167730616$ 